\title{
Submerged Speleothems and Sea Level Reconstructions: A Global Overview and New Results from the Mediterranean Sea
}

\author{
Fabrizio Antonioli ${ }^{1, *} *$, Stefano Furlani ${ }^{2}\left(\mathbb{0}\right.$, Paolo Montagna ${ }^{3}\left(\mathbb{D}\right.$, Paolo Stocchi ${ }^{4,5}$, Lucio Calcagnile ${ }^{6,7}$, \\ Gianluca Quarta ${ }^{6,7}{ }^{1}$, Jonathan Cecchinel ${ }^{8}$, Valeria Lo Presti ${ }^{9}$, Maurizio Gasparo Morticelli ${ }^{10}$, \\ Franco Foresta Martin 11,12, Edwige Pons-Branchu ${ }^{13}$ (I) and Valeria Vaccher ${ }^{2}$
}

check for updates

Citation: Antonioli, F.; Furlani, S.; Montagna, P.; Stocchi, P.; Calcagnile, L.; Quarta, G.; Cecchinel, J.; Lo Presti, V.; Morticelli, M.G.; Foresta Martin, F.; et al. Submerged Speleothems and Sea Level Reconstructions: A Global Overview and New Results from the Mediterranean Sea. Water 2021, 13, 1663. https://doi.org/10.3390/ w13121663

Academic Editor: Giorgio Anfuso

Received: 1 May 2021

Accepted: 8 June 2021

Published: 14 June 2021

Publisher's Note: MDPI stays neutral with regard to jurisdictional claims in published maps and institutional affiliations.

Copyright: (c) 2021 by the authors. Licensee MDPI, Basel, Switzerland. This article is an open access article distributed under the terms and conditions of the Creative Commons Attribution (CC BY) license (https:// creativecommons.org/licenses/by/ $4.0 /)$.
Istituto Nazionale di Geofisica e Vulcanologia (INGV), via di Vigna Murata, 00144 Rome, Italy

2 Department of Mathematics and Geosciences, University of Trieste, via Weiss 2, 34127 Trieste, Italy; sfurlani@units.it (S.F.); valeria.vaccher@units.it (V.V.)

3 Istituto di Scienze Polari (ISP), Consiglio Nazionale delle Ricerche (CNR), 40129 Bologna, Italy; paolo.montagna@cnr.it

4 NIOZ Royal Netherlands Institute for Sea Research, and Utrecht University, Landsdiep 4, 16797 SZ Horntje (Texel), The Netherlands; paolo.stocchi@nioz.nl

5 I4CCS Institute for Climate Change Solutions, University of Urbino, 61029 Urbino, Italy

6 CEDAD (Centre for Applied Physics, Dating and Diagnostics), Department of Mathematics and Physics "Ennio de Giorgi", University of Salento, 73100 Lecce, Italy; lucio.calcagnile@unisalento.it (L.C.); gianluca.quarta@unisalento.it (G.Q.)

7 INFN (Italian National Institute for Nuclear Physics), 73100 Lecce, Italy

8 Ustica Diving Center, Piazza Umberto I, 90051 Ustica, Italy; info@usticadiving.it

9 Studio Tecnico, via Montepellegrino 163, 90142 Palermo, Italy; valerialopresti@gmail.com

10 Dipartimento di Scienze della Terra e del Mare, Università di Palermo, 90100 Palermo, Italy; mauriziogasparo@unipa.it

11 Laboratorio Museo di Scienze della Terra Isola di Ustica, Rocca della Falconiera, 90051 Ustica, Italy; sidereus@rocketmail.com

12 Istituto Nazionale di Geofisica e Vulcanologia (INGV), Sezione di Palermo, via Ugo La Malfa 153, 90146 Palermo, Italy

13 Laboratoire des Sciences du Climat et de l'Environnement LSCE/IPSL, CEACNRS-UVSQ, Université Paris-Saclay, Avenue de la Terrasse, Gif-sur-Yvette, 91198 Île-de-France, France; Edwige.Pons-Branchu@lsce.ipsl.fr

* Correspondence: fabrizioantonioli2@gmail.com

Abstract: This study presents a global overview of the submerged speleothems used to reconstruct paleo sea levels and reports new results from two stalactites collected in the Mediterranean Sea. Coastal cave deposits significantly contributed to the understanding of global and regional sea-level variations during the Middle and Late Quaternary. The studied speleothems cover the last $1.4 \mathrm{Myr}$ and focused mainly on Marine Isotope Stages (MIS) 1, 2, 3, 5.1, 5.3, 5.5, 7.1, 7.2, 7.3 and 7.5. The results indicate that submerged speleothems represent extraordinary archives that can provide detailed information on former sea-level changes. The two stalactites collected in the central Mediterranean Sea, at Favignana and Ustica islands (Sicily, Italy), are both characterized by continental, phreatic or marine layers. The U-Th and ${ }^{14} \mathrm{C}$ ages of the new speleothems provide results of great interest for relative sea-level changes over the last 1000 years.

Keywords: submerged speleothem; phreatic speleothem; sea-level change; sea caves; vertical tectonic movements; Ustica; Favignana

\section{Introduction}

The study of submerged speleothems in coastal caves significantly contributed to explaining past sea-level variations for the last $1.4 \mathrm{Myr}$, especially for the climaticallyimportant Marine Isotope Stages (MIS) 1, 2, 3, 5.1, 5.3, 5.5, 6.5, 7.1, 7.2, 7.3 and 7.5. Submerged speleothems can be dated using the U-series disequilibrium methods that provide precise and accurate age determination e.g., [1-5]. These carbonate deposits are usually 
found in caves that are currently below sea level and flooded, and they often contain marine layers/encrustations or growth hiatuses that identify periods of highstands when the seawater invaded the cave and reached the speleothem.

In addition to speleothems, other biological-physical markers have been used to reconstruct past sea-level variation including shallow-water corals, lagoonal and marine cores, tidal notches, and archaeological remains that are well connected to sea-level fluctuations. However, most of these indicators exhibit large uncertainties in age determination due to sample alteration and / or in absolute elevation (e.g., paleowater depth for corals). Submerged speleothems that have been studied so far include (1) continental (vadose) carbonates, in a few cases containing hiatuses; (2) speleothems with overgrowth(s) of marine organisms (e.g., the marine polychaete worm Serpula massiliensis, bryozoans and sponges); and (3) speleothems with phreatic overgrowth(s). The general features of these carbonate cave deposits are described in [6]. In the Mediterranean Sea, more than 300 submerged speleothems were sampled in 32 caves and more than half were analyzed for paleo sea-level reconstructions (Figure 1) [6].

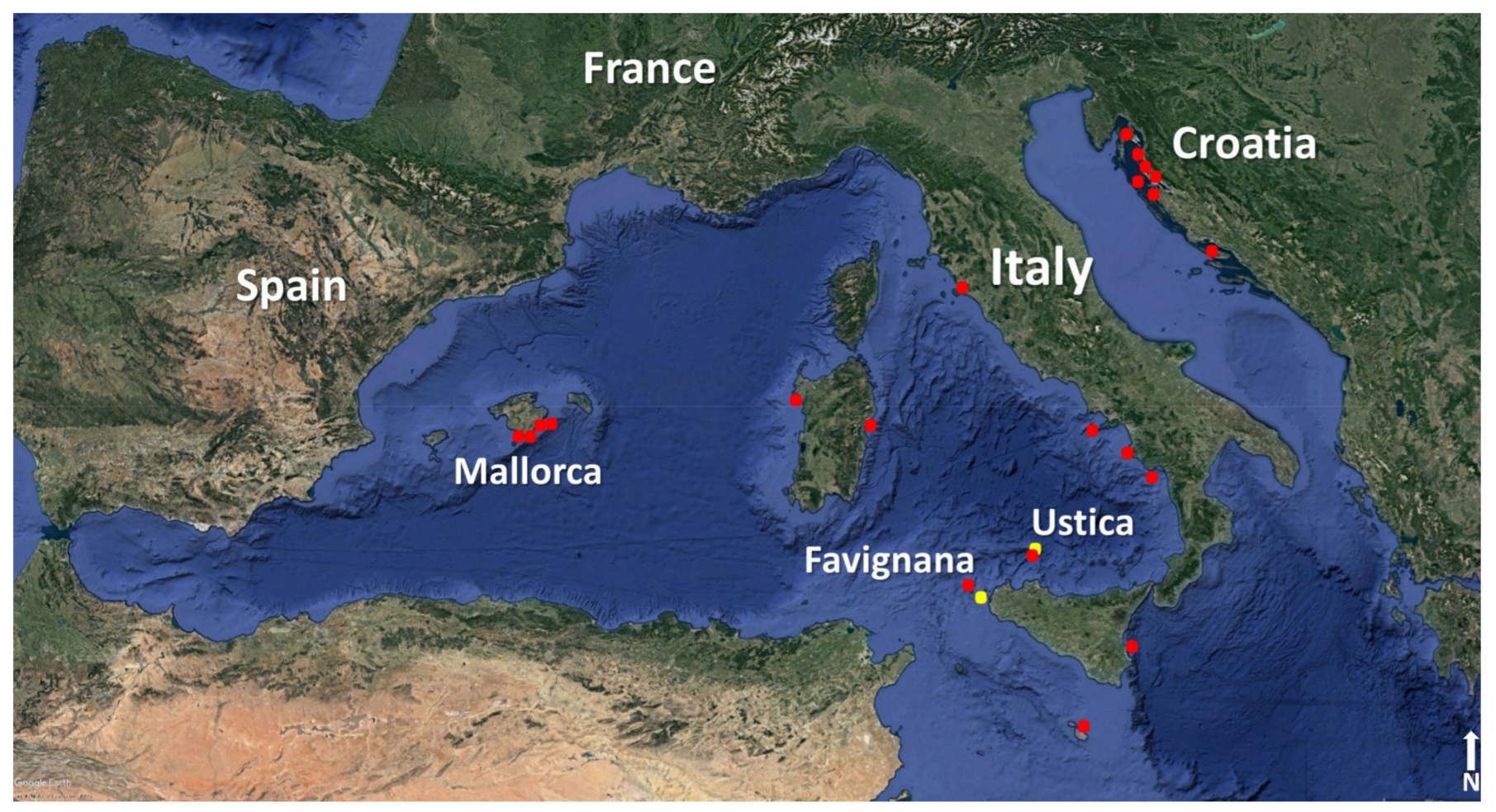

Figure 1. Overview of the Mediterranean region showing the locations (red dots) of the submerged caves discussed in [6] and the new sites (yellow dots) at Favignana and Ustica.

Other speleothem-based sea-level records come from sites in the Caribbean region (Yucatán Peninsula and Cuba), The Bahamas, Bermuda, and Japan (Minami Daitō island) (Figures 2 and 3), which show very different geological and stratigraphic structures.

Here, we provide a comprehensive review of published sea-level reconstructions based on submerged speleothems and present new data from two stalactites collected from the Ustica and Favignana islands in the central Mediterranean Sea. Published data for the Mediterranean Sea have recently been summarized in [6]. Some of the most important findings have come from speleothems retrieved from flooded coastal caves worldwide, often exhibiting hiatuses or marine overgrowths, and the submerged cave deposits in The Bahamas [3,4,7], Bermuda [8,9], Yucatán Peninsula [10,11], Cuba [12], and Japan [13] merit special attention. There have been exhaustive reviews of the use of sea-level indicators preserved in coastal caves including speleothems and cave sedimentary deposits [14,15]. 


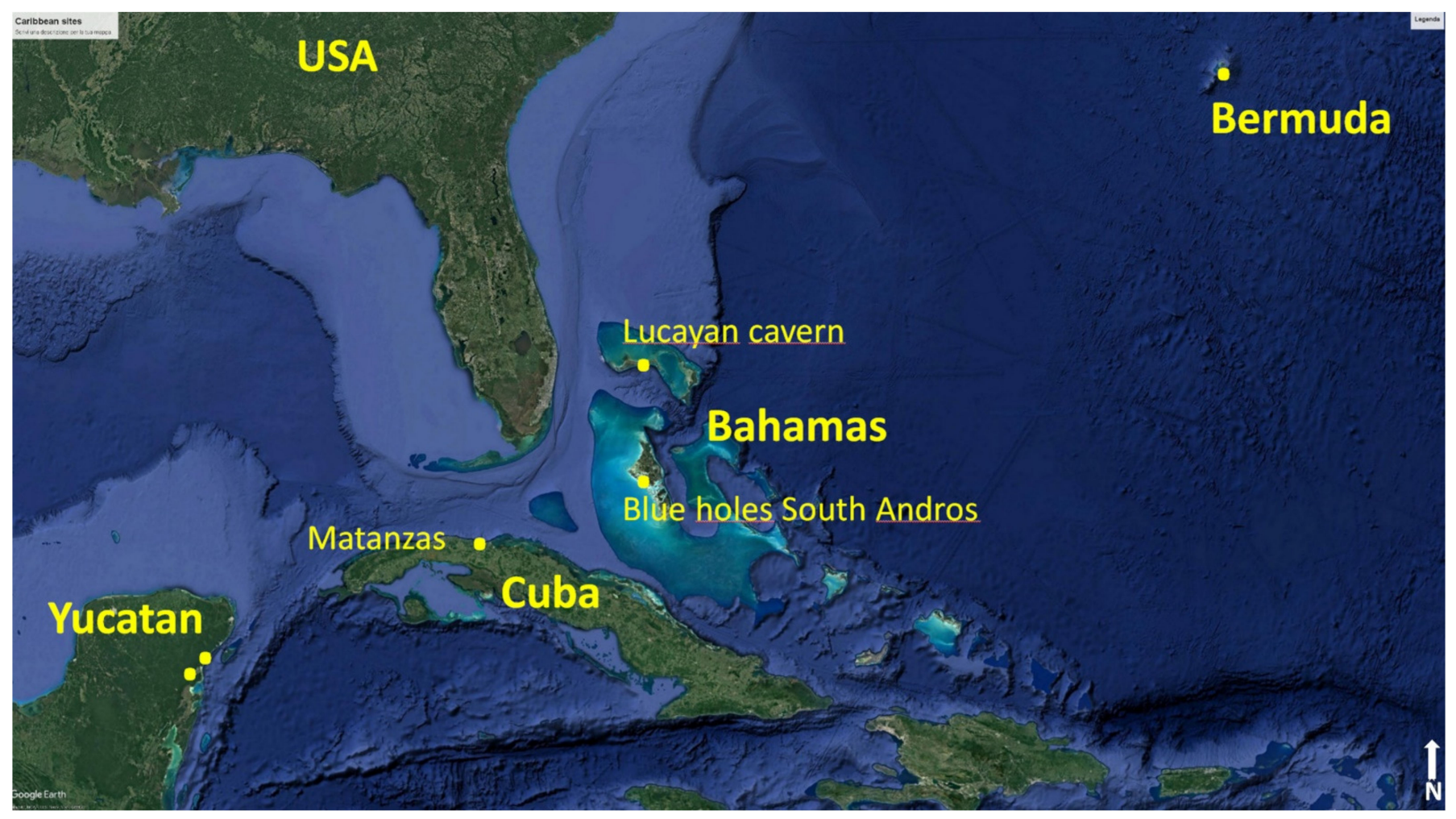

Figure 2. Overview of the Caribbean region showing the locations of the submerged caves or cenotes discussed in this study. Specific information (latitude, longitude, sampling depths, dating method, ages) is reported in Table 1.

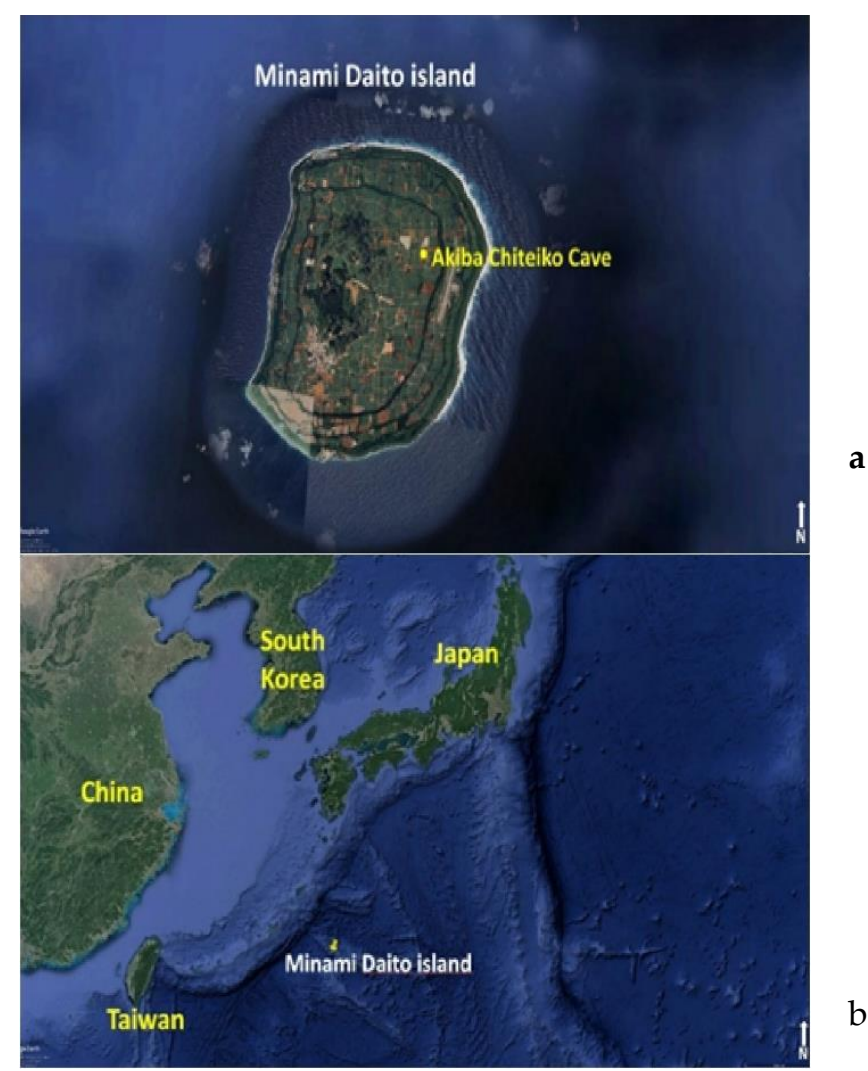

Figure 3. Minami Daito island (Japan) in relation to surrounding geography (a) and at a smaller scale (b). Specific information (latitude, longitude, sampling de1pths, dating method, ages) is reported in Table 1. 


\section{Materials and Methods}

\subsection{Western North Atlantic-Caribbean Region and Northern Philippine Sea}

Sea-level reconstructions based on vadose speleothems and marine overgrowths from the Yucatán Peninsula have been obtained by $[10,11]$, through the analysis of samples collected at elevations between +1.5 and $-15.1 \mathrm{~m}$. The Yucatán Peninsula is located in southeastern Mexico and separates the Caribbean Sea from the Gulf of Mexico. It is almost entirely composed of carbonate and soluble rocks, being mostly limestone although dolomite and evaporites are also present at various depths [16]. The whole Yucatán Peninsula is an unconfined flat lying karst landscape. Sinkholes, locally known as cenotes, are widespread in the northern lowlands [17]. The samples studied by $[10,11]$ formed within Plio-Pleistocene reef and back-reef limestones in a tectonically stable area with little deformation [18].

Phreatic overgrowths and speleothems from Santa Catalina Cave on the northern coast of Cuba were investigated by $[12,19]$. This cave is carved into Late Pliocene-Early Pleistocene reef limestones [20] and hosts a variety of normal and exotic speleothems, including the mushroom-shaped speleothems, which precisely mark the water level.

Several speleothems and flowstones were studied by $[3,4]$ in The Bahamas for past sea-level reconstruction. The Bahamas islands include aeolian sands and limestone built on the basement rock of the Florida-Bahamas Platform and are considered a quasi-stable

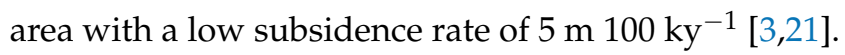

Speleothems and marine aragonite overgrowths were analyzed by [8,9] in Bermuda. This volcanic seamount is located in the central-western Atlantic and has a carbonate cap with eolian limestone interbedded with paleosol layers. The island's volcanic basement rock is relatively shallow $(75 \mathrm{~m}$ below sea level, bsl) and includes $700 \mathrm{~m}$ of tholeiitic lava aged 33 million years. The oceanic crust around the island is about 120 million years old. Bermuda is considered a tectonically stable island but a "near field" with respect to forebulge ice [22].

Phreatic overgrowths on speleothems (POS) were studied by [13] in the Minami Daito island in Japan (northern Philippine Sea) to reconstruct Holocene sea-level variations. The island was formed as an atoll in the mid-Eocene (ca. $42 \mathrm{Ma}$ ago) on a subsiding volcanic edifice [23] and experienced an average uplift rate of $5 \mathrm{~cm} \mathrm{ky}^{-1}$ over the last $125 \mathrm{ky}$. The island is considered stable based on fossil tidal notches and dated corals [24].

Table 1 reports the basic information of the cave deposits from the western North Atlantic-Caribbean region and Minami Daito island. For further information regarding the cave morphology, sampling method used, date of sampling, and the error associated with the radiocarbon and U-Th ages, please refer to the original publications $[3-5,10-13,19,25-38]$.

\subsection{Mediterranean Region}

The coastline in the Mediterranean Sea (MS) extends for about $46,000 \mathrm{~km}$, with approximately half being rocky and characterized by plunging cliffs, sloping coasts, screes, and shore platforms [39]. The MS experiences warm and dry summers and mild and rainy winters owing to its geographic position at the boundary between the subtropical and mid-latitude zones [40]. It is a highly evaporative basin that is connected with the Atlantic Ocean through the Strait of Gibraltar (sill depth $\approx 300 \mathrm{~m}$ ) and with the Black Sea through the Strait of Dardanelles (sill depth $\approx 100 \mathrm{~m}$ ) and the Bosphorus Strait (sill depth $\approx 65 \mathrm{~m}$ ). The coastal geometry and bathymetry of the MS, together with weather conditions, strongly control the tidal amplitude that varies along the Mediterranean coast. The average tidal amplitude is about $40 \mathrm{~cm}$, with the exception of the large tides in the Gulf of Gabes (Tunisia) and in some areas of the North Adriatic Sea, where they may reach amplitudes of up to $1.80 \mathrm{~m}$. In general, the Mediterranean tides have lower amplitudes compared to the other oceanic basins. 


\subsection{Ustica Island}

Ustica Island (central MS, Figure 1) represents the emerged part of a submarine volcano that rises more than $2200 \mathrm{~m}$ from the bottom of the southern Tyrrhenian Sea and lies on a deformed continental crust (15-20 km; [41]) along the Africa-Europe plate boundary [42]. The island is located about $60 \mathrm{~km}$ north of Palermo (northwest Sicily coast) and covers an area of $8.6 \mathrm{~km}^{2}$, reaching a maximum elevation of $248 \mathrm{~m}$ a.s.l. The structural pattern of Ustica Island and its offshore area is characterized by ENE-WSW and N-S directed extensional and compressional fault systems [42-44]. The island is made up of alkali-basaltic to trachytic composition lava flow and pyroclastic products [45-49] that are locally covered by marine and continental sedimentary deposits [50]. The present morphology of Ustica Island and its offshore area results from the prolonged interplay between volcanic, tectonic, and eustatic processes [42,51], which have been active since the Pleistocene and contributed to the birth of the island between 750 and $130 \mathrm{ky} \mathrm{ago}$, as demonstrated by stratigraphic and geochronological studies carried out on exposed rocks [49,52].

In the volcanic history of Ustica Island, there have been several overlapping cycles of marine ingression and regression, resulting from Middle-Upper Pleistocene glacio-eustatic movements. The sea-level stands related to these oscillations generated typical sedimentary terraces and submerged plains [42,51], which were later uplifted by tectonics at variable height from their original position. Five orders of level surfaces have been identified at heights ranging from about $100 \mathrm{~m}$ asl for the oldest and highest terrace, to $5 \mathrm{~m}$ asl for the most recent and lowest terrace $[49,53]$. The occurrence of marine terraces of variable age at decreasing elevations from the oldest to the youngest helps to define the amount of uplift recorded by the island, which must have been no more than $120 \mathrm{~m}$, at least since the formation of the oldest level surface, which is $350 \mathrm{ky}$ ago [49,53].

Regarding the geological long-term vertical movements, the maximum elevation of MIS 5.5 is $33 \mathrm{~m}$ [52], with an uplift rate of $0.21 \mathrm{~mm} \mathrm{yr}^{-1}$. The recent discovery of fossil barnacle (genus Chthamalus) bands radiocarbon dated to $1823 \pm 104 \mathrm{yr}$ Anno Domini AD and covered by a flowstone dated to $1894 \pm 24 \mathrm{yr}$ AD in the Grotta Segreta [51] reveals a coseismic event. An uplift of at least $40 \mathrm{~cm}$ is suggested that might be related to the strong earthquake in 1906, which forced the human population to evacuate the island. This example advises against the use of instrumental data alone for the long-term projections of future sea-level rise by 2100 (i.e., GPS data do not reveal vertical movements at Ustica).

\subsection{Favignana Island}

Favignana Island (Egadi Archipelago, Figure 1) is the closest island to Sicily. The archipelago was formed by carbonate and terrigenous Meso-Cenozoic deposits pertaining to different paleogeographic domains, covered by unconformable Plio-Quaternary pelagites and clastics. MIS 5.5 calcarenite and biorudite outcrops $[54,55]$ are widely distributed in the eastern sector of Favignana, from 5 to $10 \mathrm{~m}$ [56]. Favignana and Egadi islands are considered to have been stable or slightly uplifted areas for at least the last $125 \mathrm{ky}$ [57-59]. Many outcrops of polygenic conglomerates contain fossil shells of Senegalese fauna including Persistrombus latus (previously Strombus bubonius). Uplifted Middle Pleistocene (MIS 9-11) forms and deposits reach an elevation of $40 \mathrm{~m}$ [56].

\subsection{Speleothem Sampling in Favignana and Ustica Islands}

A partly submerged stalactite was collected in 2016 from Stalattiti cave (Figures 1 and 4) on Ustica Island (about $1.4 \mathrm{~km}$ from the harbor, Figure 5) using a hammer. At the time of the sampling, the deepest portion of the speleothem was $40 \mathrm{~cm}$ below sea level. Elevation measurements were corrected for tide and pressure in order to relate them to the mean sea level (MSL) by using data from the tide gauges of Palermo (www.wxtide32.com) and the meteorological website www.wunderground.com. The correction used was $7 \mathrm{~cm}$ for a $1019 \mathrm{hPa}$ pressure. The uncertainty on the elevation measurements of the partly submerged speleothem relative to the sea level, which is on the order of few centimeters, 
can be considered negligible, even though large uncertainties may arise from the assumed sea-level position of markers (Table 1).

A partly submerged stalactite was retrieved in 2014 from Stalattiti cave (Figures 1 and 6) on the north-east coast of Favignana Island using a hammer. At the time of the sampling, the deepest portion of the speleothem was $30 \mathrm{~cm}$ below sea level. Elevation measurements were corrected for tide and pressure in order to relate them to the mean sea level (MSL) by using data from the tide gauges of Marsala (www.wxtide32.com) and from the meteorological website www.wunderground.com. The correction was $2 \mathrm{~cm}$ for a pressure of $1015 \mathrm{hPa}$.

The uncertainty of the elevation measurements of the partly submerged speleothem relative to the sea level, which is in the order of few centimeters, can be considered negligible, even though large uncertainties may arise from the assumed sea-level position of markers (Table 1).

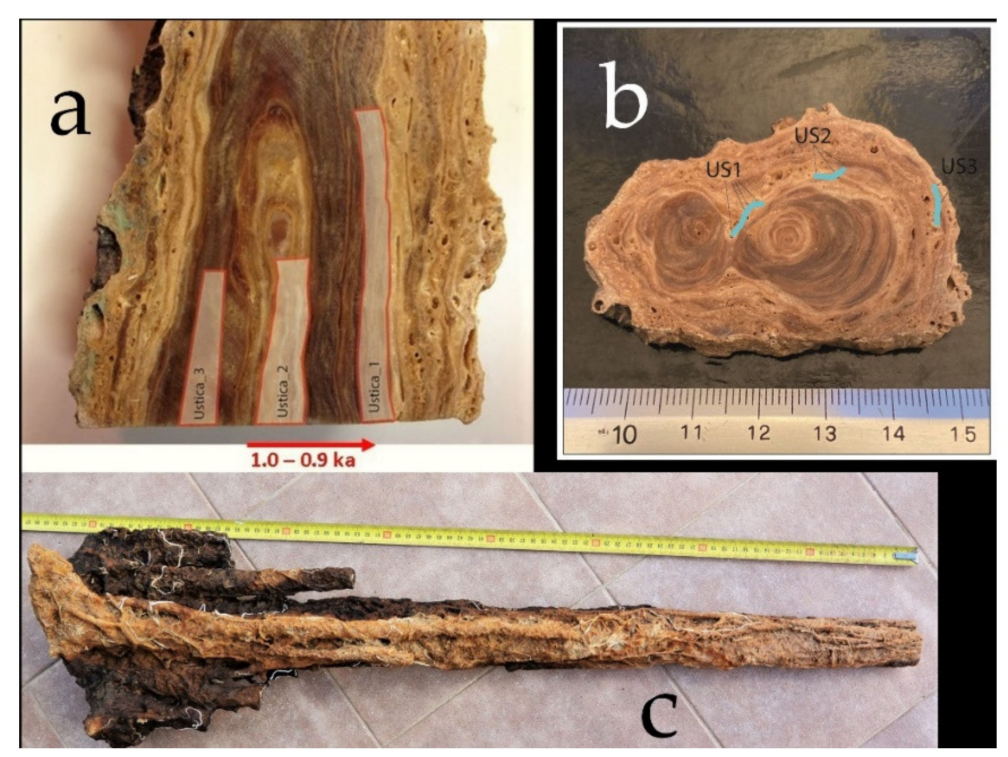

Figure 4. The stalactite sampled at Ustica: (a) Longitudinal section with sampling area of $U \backslash$ Th ages (refer to Table 2); (b) horizontal Scheme 1. US2, and US3, refer to Table 3; (c) the stalagmite sampled.

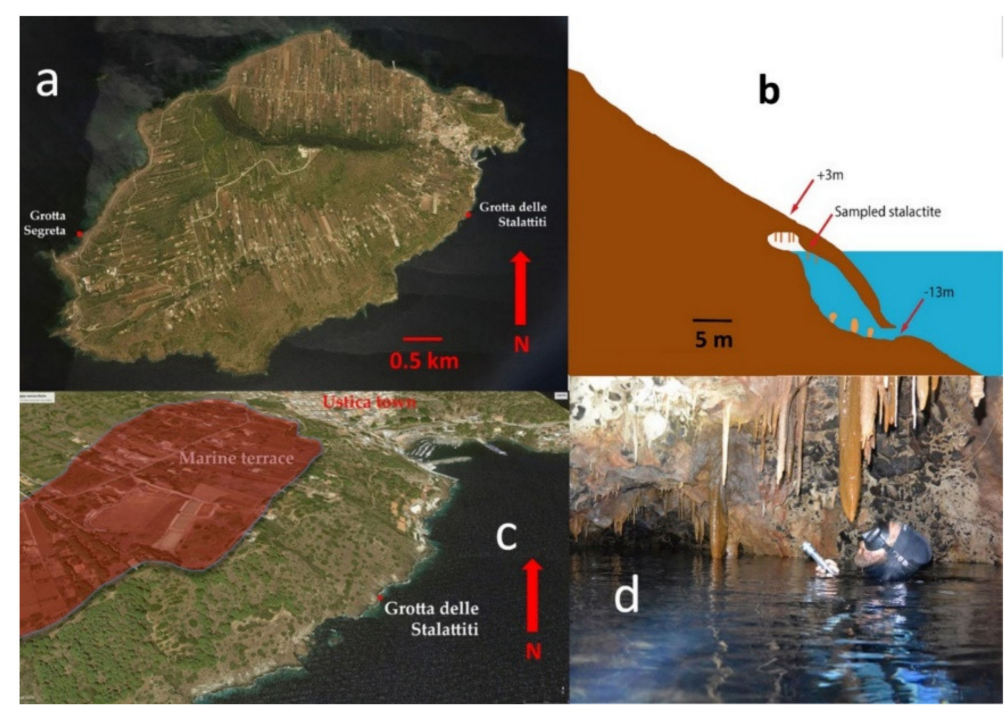

Figure 5. (a) Ustica and the location of the Grotta delle Stalattiti and Grotta Segreta caves. (b) Section of the Stalattiti cave. (c) Location of Stalattiti cave, Ustica town, and a well-carved marine terrace aged MIS 9 [53]. (d) Inside the cave at the sampling area, at sea level in an air bubble. 


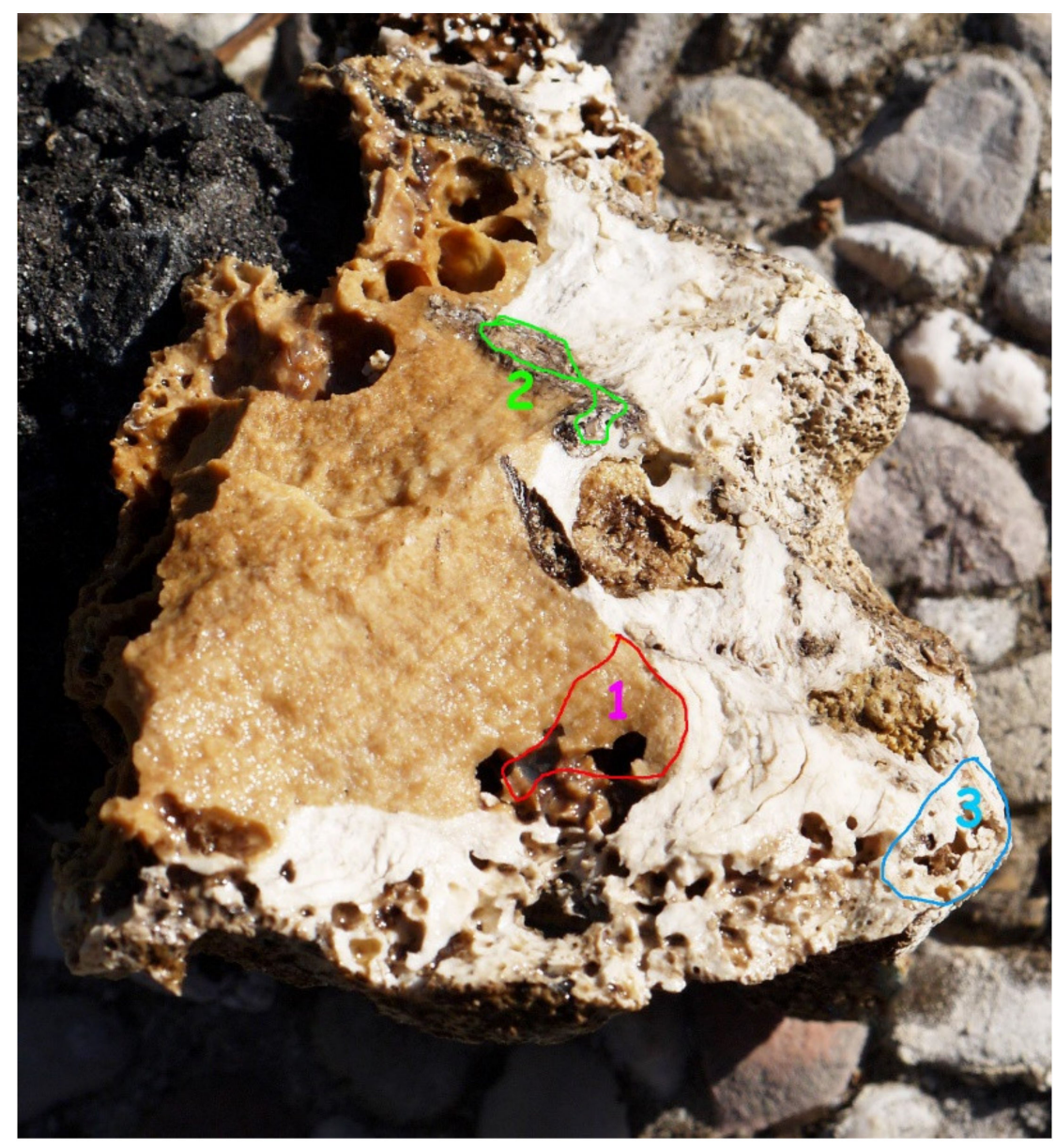

Figure 6. Section of the stalactite sampled at Favignana Island: (1) Continental portion sedimented during MIS 2 (Table 2); (2) the area highlighted in green contains a narrow (3-4 mm) band of marine deposition (Serpulids); (3) the final portion of the speleothem is composed by a stratified white carbonate, typical of phreatic deposition.

\subsection{U-Th and ${ }^{14} \mathrm{C}$ Dating}

Three fragments of spelean calcite ( $300 \mathrm{mg})$ were collected within the vadose portion of the stalactite from Ustica Island (Figures 4 and 5) and analyzed through the U-series disequilibrium method to determine their absolute age. The fragments were carefully cleaned using a small diamond blade to remove any visible contamination and dissolved with diluted $\mathrm{HCl}$ before being mixed with known concentrations of ${ }^{229} \mathrm{Th},{ }^{233} \mathrm{U}$ and ${ }^{236} \mathrm{U}$, and calibrated against a Harwell Uraninite solution (HU-1) assumed to be at secular equilibrium. The uranium and thorium fractions were separated using UTEVA resin (Eichrom Technologies, Lisle, IL, USA) and analyzed by standard-sample bracketing using a Thermo Scientific Neptune ${ }^{\text {Plus }}$ multi-collector inductively coupled plasma-mass spectrometer at the Laboratoire des Sciences du Climat et de l'Environnement (LSCE) (Gif-sur-Yvette) following the protocol developed at LSCE [60]. The ${ }^{230} \mathrm{Th} / \mathrm{U}$ ages were calculated from measured atomic ratios through iterative age estimation [61] using the ${ }^{230} \mathrm{Th},{ }^{234} \mathrm{U}$ and ${ }^{238} \mathrm{U}$ decay constants of [62] and [63]. A correction was applied for the non-radiogenic (detrital) ${ }^{230} \mathrm{Th}$ fraction using an initial ${ }^{230} \mathrm{Th} /{ }^{232} \mathrm{Th}$ activity ratio of $1.5 \pm 0.75$. However, due to the low ${ }^{232} \mathrm{Th}$ concentration $(<0.05 \mathrm{ng} / \mathrm{g})$ and high ${ }^{230} \mathrm{Th} /{ }^{232} \mathrm{Th}$ ratio $(>700)$, the detrital correction had a negligible effect (Table 2). 


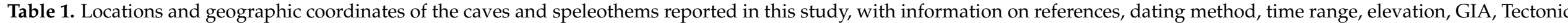
corrections and local tide (https://www.tide-forecast.com/).

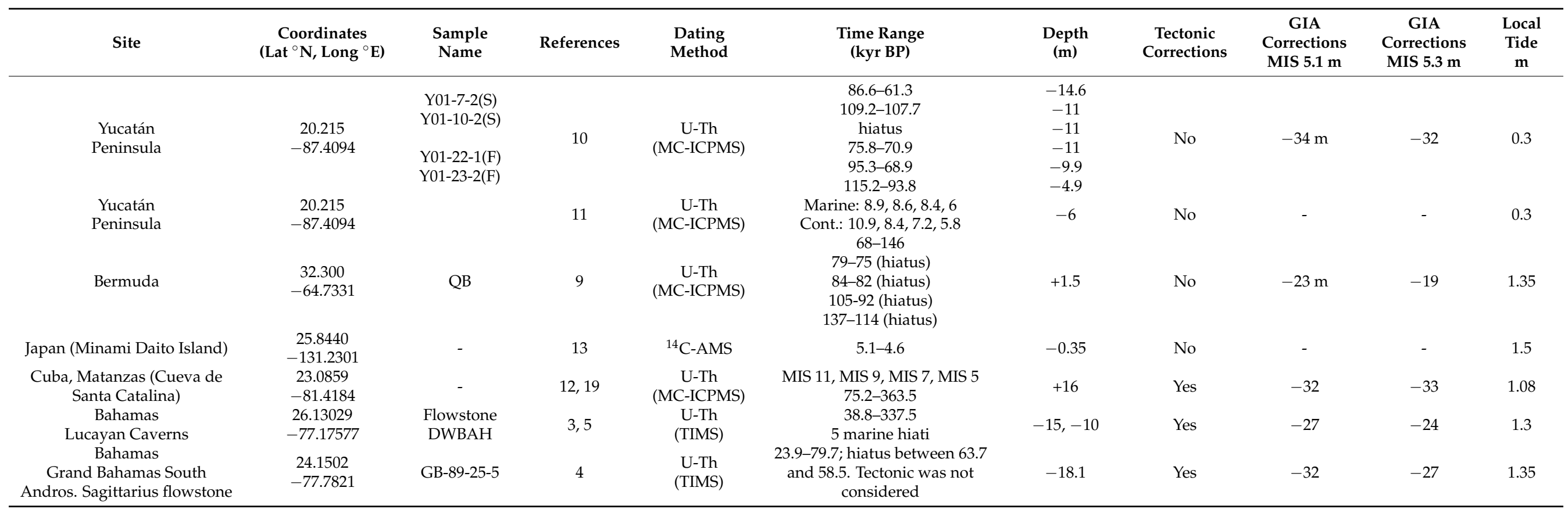


Table 2. Results of the U/Th dating of the vadose speleothem (Ustica 1, 2, 3; Figure 5). ${ }^{238} \mathrm{U}$ and ${ }^{232} \mathrm{Th}$ concentrations were determined using the enriched ${ }^{236} \mathrm{U}$ and ${ }^{229} \mathrm{Th}$ isotopes, respectively. $\delta^{234} \mathrm{U}_{\mathrm{m}}=\left\{\left[\left({ }^{234} \mathrm{U} /{ }^{238} \mathrm{U}\right)_{\text {sample }} /\left({ }^{234} \mathrm{U} /{ }^{238} \mathrm{U}\right)_{\mathrm{eq}}\right]-1\right\} \times 1000$, where $\left({ }^{234} \mathrm{U} /{ }^{238} \mathrm{U}\right)_{\text {sample }}$ is the measured atomic ratio, $\left({ }^{234} \mathrm{U} /{ }^{238} \mathrm{U}\right)_{\mathrm{eq}}$ is the atomic ratio at secular equilibrium, and $\delta^{234} \mathrm{U}_{(0)}$ corr is the initial value and was calculated by the following equation: $\delta^{234} U_{(0)}=\delta^{234} U_{m} \exp \left(\delta_{234} t\right)$, where $t$ is the corrected age in years and $\delta_{234}$ is the decay constant for ${ }^{234} \mathrm{U}$. * Ages corrected for detrital ${ }^{230} \mathrm{Th}$ using an inital ${ }^{230} \mathrm{Th} /{ }^{232} \mathrm{Th}$ activity ratio of $0.85 \pm 0.36$ [64].

\begin{tabular}{|c|c|c|c|c|c|c|c|}
\hline Sample & $\left({ }^{238} \mathrm{U}\right)$ & $\left({ }^{232} \mathrm{Th}\right)$ & $\delta^{234} U_{m}$ & $\left({ }^{230} \mathrm{Th} /{ }^{238} \mathrm{U}\right)_{\text {act }}$ & $\left({ }^{230} \mathrm{Th} /{ }^{232} \mathrm{Th}\right)_{\mathrm{act}}$ & Age & Age corr \\
\hline & $(\mu g / g)$ & (ng/g) & (\%o) & & & (kyr) & $(\operatorname{kyr} B P)$ * \\
\hline Ustica-1 & $1.194(0.001)$ & $0.0483(0.0005)$ & $67.4(0.6)$ & $0.00939(0.00007)$ & $\begin{array}{c}702.7 \\
(5.4)\end{array}$ & $0.97(0.01)$ & $0.89(0.01)$ \\
\hline Ustica-2 & $1.143(0.001)$ & $0.0340(0.0004)$ & $67.5(0.8)$ & $0.01024(0.00023)$ & $\begin{array}{l}1041.5 \\
(24.0)\end{array}$ & $1.05(0.03)$ & $0.98(0.03)$ \\
\hline Ustica-3 & $1.543(0.002)$ & $0.0236(0.0005)$ & $70.5(0.9)$ & $0.00989(0.00021)$ & $\begin{array}{l}1944.3 \\
(42.3)\end{array}$ & $1.01(0.02)$ & $0.95(0.02)$ \\
\hline
\end{tabular}

Table 3. Radiocarbon data for Favignana Island stalactite cave. Column 1: * are from [65]. Column 4 * unavailable error bar. The obtained conventional radiocarbon ages were calibrated by using the Calib 8.10 software [66].

\begin{tabular}{|c|c|c|c|c|c|}
\hline Sample & $\begin{array}{c}\text { Corrected } \\
\text { Altitude }(\mathrm{cm})\end{array}$ & $\begin{array}{c}\text { Radiocarbon } \\
\text { Age (BP) }\end{array}$ & $\delta^{13} \mathrm{C}(\%)$ & Kind of markers & $\begin{array}{l}\text { Cal BP } \\
1 \text { Sigma }\end{array}$ \\
\hline LTL15761A & $-32 \pm 5$ & $1912 \pm 45$ & $+2 \pm 0.7$ & S2 serpulids & $\begin{array}{l}1485-1304 \\
1395 \pm 45\end{array}$ \\
\hline LTL15762A & $-35 \pm 15$ & $806 \pm 45$ & $+3 \pm 0.5$ & S3 phreatic & $\begin{array}{l}735-675 \\
705 \pm 30\end{array}$ \\
\hline LTL15762B & $-32 \pm 5$ & $19,886 \pm 100$ & $-29.5 \pm 0.5$ & S1 continental & $\begin{array}{c}24,013-23,795 \\
23,903 \pm 109\end{array}$ \\
\hline $\mathrm{R}-2741$ * & $-30 \pm 10$ & $531 \pm 32$ & +1.40 * & $\begin{array}{c}\text { Cala Mancina } \\
\text { St Vito Lo Capo }\end{array}$ & $\begin{array}{c}232-106 \\
169 \pm 63\end{array}$ \\
\hline $\mathrm{R}-2742$ * & $-30 \pm 10$ & $527 \pm 36$ & +1.33 * & $\begin{array}{c}\text { Cala Mancina } \\
\text { St Vito Lo Capo (Tp) }\end{array}$ & $\begin{array}{c}232-94 \\
163 \pm 69\end{array}$ \\
\hline $\mathrm{R}-2764$ * & $-30 \pm 10$ & $554 \pm 35$ & +1.31 * & Calazza (Pa) & $\begin{array}{c}251-127 \\
189 \pm 62\end{array}$ \\
\hline $\mathrm{R}-2580$ * & $-40 \pm 10$ & $784 \pm 37$ & $+1.76^{*}$ & Barcarello (Pa) & $\begin{array}{c}412-146 \\
279 \pm 133\end{array}$ \\
\hline
\end{tabular}

Radiocarbon dating for the Ustica and Favignana samples was carried out at CEDADCentre for Applied Physics, Dating and Diagnostics at the University of Salento [67]. The selected samples were carefully removed from the matrix using a diamond blade. The extracted portion of the sample was analyzed using an optical microscope in order to identify and mechanically remove adhering particles or unwanted fractions of the matrix. The sample was then attacked with $\mathrm{H}_{2} \mathrm{O}_{2}$ in order to remove the uppermost layer and then hydrolyzed under vacuum to $\mathrm{CO}_{2}$ by using $\mathrm{HCl}$. Extracted $\mathrm{CO}_{2}$ was then catalytically reduced to graphite, which was then used to measure the radiocarbon age by AMS (Accelerator Mass Spectrometry). The radiocarbon dating beamline was used based on a 3MV Tandetron accelerator (Mod. HVEE 4130HC) to measure the radiocarbon content. After correction for the machine and processing background, the conventional radiocarbon age of the samples was calculated. For continental samples, conventional radiocarbon ages were calibrated using the INTCAL20 calibration curve, while marine samples were calibrated using the MARINE20 [68] curve and a local $\Delta \mathrm{R}=-88 \pm 50 \mathrm{y}$ (Table 4, Figure 5) [69]. 
Table 4. Radiocarbon data of the outer overgrowth of Ustica stalactite. The Note column shows the sample name used in Figure 5b.

\begin{tabular}{ccccc}
\hline Sample in Section & Sample & Radiocarbon Age (BP) & $\mathbf{\delta 1 3 C}(\mathbf{\% o})$ & Note \\
\hline 1 & LTL20043A & $2231 \pm 45$ & $-18.3 \pm 0.6$ & US1 \\
2 & LTL20044A & $1954 \pm 45$ & $-17.1 \pm 0.7$ & US2 \\
3 & LTL20045A & $1929 \pm 45$ & $-23.7 \pm 0.4$ & US3 \\
\hline
\end{tabular}

\subsection{Numerical Modelling of Glacial- and Hydro-Isostatic Adjustment and Sea-Level Change}

Land-based sea-level indicators, such as speleothems, keep track of past sea-level changes that are referenced to the surface of the solid earth. As the latter can be affected by vertical motions, the recorded sea-level fluctuations in speleothems are defined as local relative sea-level changes (RSL).

In particular, ice-driven sea-level changes stem from the contribution of ocean mass variation in response to continental ice mass variation, as well as solid earth deformations and vertical geoid perturbations [70-72]. In fact, when water mass is transferred from ice sheets to oceans and vice versa, solid earth deforms in order to restore the isostatic equilibrium under a different surface loading setting. Solid earth deformations and ice masses behave as density anomalies, thus affecting the vertical position of the mean sea surface, which is an equipotential surface of gravity (geoid). This process, known as glacialand hydro-isostatic adjustment (GIA), is responsible for regionally varying RSL changes that are modulated in time with the viscous flow of mantle material.

As a result of mass conservation, the ocean average RSL change corresponds to the global mean, or eustatic, sea-level change. Based on the geographical distance from the ice sheets, local RSL change can either be very close to (ice distal or far-field regions), or significantly different from the eustatic sea-level change (ice proximal areas). The largest deviations from the eustatic signal are found where ice sheets grow and shrink. In particular, during glacial periods and beneath the growing ice sheets, the crust subsides and forces the upper mantle material to flow outwards, thus causing uplift of the ice-proximal peripheral area that forms the so-called forebulge. Between the forebulge and the ice margins, the local RSL rises due to the crustal subsidence and the geoid uplift that is caused by the gravitational pull that the ice masses exert on the ocean water. On top of the forebulge, the local RSL drop is much larger than the eustatic equivalent during glacial periods because of the combination of crustal uplift and geoid subsidence. When the ice sheets melt, the ice-covered areas undergo uplift, while the forebulge areas experience strong subsidence that, combined with the eustatic signal, results in a much higher-than-average RSL rise. The vertical motions that affect the forebulge areas are not just relevant for the ice proximal location, but also for the far-field equatorial and continental coastal areas. Here, in fact, despite the distance from the ice sheets, the RSL changes that follow major deglaciations may strongly deviate from the eustatic change. Due to mass conservation, ocean water flows towards the subsiding peripheral forebulges, which locally results in an RSL drop that follows an initial highstand. This process is known as ocean syphoning. Interestingly, some of the Caribbean and Yucatán speleothems are in areas where complex forebulge ocean syphoning dynamics operate.

Therefore, RSL indicators provide constraints on the chronologies of past ice sheets and on the relevant earth rheological parameters that regulate the deformation of the planet in response to surface ice and water loading.

To compute local ice-driven relative sea-level change, the gravitationally self-consistent sea-level equation (SLE; 1-4) must be solved for a prescribed ice sheet chronology and earth rheological model. The SLE is a linear equation that yields, for any variation of landbased (i.e., grounded) ice thickness, the time- and space-dependent vertical deformation of the mean sea surface and the solid earth surface. The difference between the two is the relative sea-level (RSL) change. We employed SELEN [70-72] to solve the SLE and retrieve the local GIA-modulated RSL curves at each site. The most up-to-date version of 
open-source model SELEN includes the rotational feedbacks as well as the form treatment of the time-dependent ocean function (i.e., variable coastlines).

We assumed a self-gravitating, rotating, spherically symmetric, radially stratified, deformable but not compressible Earth model. The latter is one-dimensional, and all the relevant rheological parameters depend on the Earth's radius only. The outer shell of the model is perfectly elastic and represents the lithosphere. Between the lithosphere and the inviscid core is the mantle, which was characterized by linear Maxwell viscoelastic rheology. The mantle can be discretized into a number of layers.

First, we discretized the VM2 mantle viscosity profile [73] over a four-layer model where the upper mantle (UM), lower upper mantle (LUM), transition zone (TZ) and lower mantle (LM) are characterized by a Maxwell viscoelastic rheology and laterally uniform viscosity (Tables 5 and 6). We combined this with a lithosphere thickness of $90 \mathrm{~km}$. We used this as a reference model to be combined with three ice sheet chronologies.

Table 5. Elastic lithosphere thickness and viscosity of the four-layer VM2 profile.

\begin{tabular}{cccccc}
\hline VM2 & LT $(\mathbf{k m})$ & UM $\left(\times \mathbf{1 0}^{\mathbf{2 1}} \mathbf{P a} \cdot \mathbf{s}\right)$ & LUM $\left(\times \mathbf{1 0}^{\mathbf{2 1}} \mathbf{P a} \cdot \mathbf{s}\right)$ & TZ $\left(\times \mathbf{1 0}^{\mathbf{2 1}} \mathbf{P a} \cdot \mathbf{s}\right)$ & $\mathbf{L M}\left(\times \mathbf{1 0}^{\mathbf{2 1}} \mathbf{P a} \cdot \mathbf{s}\right)$ \\
\hline 90 & 0.67 & 0.44 & 0.46 & 2.53 \\
\hline
\end{tabular}

Table 6. Elastic lithosphere thickness and viscosity of the three-layer MVP 1-3 profiles.

\begin{tabular}{|c|c|c|c|c|}
\hline MVPs & LT (km) & $\mathrm{UM}\left(\times 10^{21} \mathrm{~Pa} \cdot \mathrm{s}\right)$ & $\mathrm{TZ}\left(\times 10^{21} \mathrm{~Pa} \cdot \mathrm{s}\right)$ & $\mathrm{LM}\left(\times 10^{21} \mathrm{~Pa} \cdot \mathrm{s}\right)$ \\
\hline MVP1 & 100 & 1 & 1 & 2 \\
\hline MVP2 & 100 & 0.5 & 0.5 & 5 \\
\hline MVP3 & 100 & 0.25 & 0.5 & 10 \\
\hline
\end{tabular}

We employed the following ice-sheet models:

- ICE-5G [73]: This global model describes the ice-sheet thickness variation over North America, Eurasia, Greenland and Antarctica during the last $123 \mathrm{ka}$. Geological and modern geodetical observations were used to constrain the ice thickness chronology between $26 \mathrm{ka}$ and the present day [6]. Through an iterative procedure, the SLE was solved for an a priori ice-sheet configuration and a prescribed fixed solid earth model (mantle viscosity profile and lithosphere thickness). The predicted RSL elevations and modern vertical rates were compared with paleo RSL indicators and measured crustal and geoidal vertical velocities, respectively. The differences between predictions and observations were then used to modify the ice-sheet models until a satisfactory solution is found. The ice-sheet volumetric evolution between 123 and $26 \mathrm{ka}$ was tuned to the $\delta^{18} \mathrm{O}$ curve [74] and loosely constrained by surface geological evidence that defines the ice margins. Here, we combined two ICE-5G chronologies in order to cover the time span under consideration and to evaluate the GIA-modulated RSL response to the melting of the MIS 6 ice sheets during the MIS 5e. The latter is characterized by $\mathrm{a} \approx 0.9 \mathrm{~m}$ eustatic sea-level highstand above the present-day mean sea level of between $129.5 \mathrm{ka}$ and $123 \mathrm{ka}$, mostly coming from a reduced (with respect to present-day) Greenland Ice Sheet.

- ICE-6G [75]: This model is a modified version of ICE-5G. Here, we applied the same repetition as in the series of ICE-5G. According to the ICE-6G, the maximum MIS 5.5 eustatic highstand between $129 \mathrm{ka}$ and $123 \mathrm{ka}$ is $\approx 3.1 \mathrm{~m}$ above present-day msl as a consequence of reduced Greenland and West Antarctic Ice Sheets

- ANICE-SELEN [76,77]: This global chronology model is the result of an inverse forward modelling procedure where the $\delta^{18} \mathrm{O}$ stack [74] is decoupled into global icesheet volume and deep-water temperature. For this purpose, 3D thermomechanical ice-sheet models for North America, Eurasia, Greenland and Antarctica are dynamically coupled to SELEN to include all the GIA feedbacks. ANICE-SELEN is not yet 
constrained by geological or instrumental data. Here, we used the original ANICESELEN chronology, which is characterized by $\approx 2.5 \mathrm{~m}$ eustatic highstand during MIS 5 e (125-117 ka), in response to a reduced Greenland Ice-Sheet volume.

The temporal volume variation of the three ice-sheet models is dependent, to a certain degree, on the benthic oxygen curve [74].

\section{Results}

This section is divided into two parts: The first reports published data in the Western North Atlantic-Caribbean region and Japan (Section 3.1), while the second reports new data from the MS (Section 3.2).

\subsection{Review Data}

\subsubsection{Bermuda}

The Western North Atlantic-Caribbean region, and Bermuda in particular, is strongly affected by the vertical motions of the periglacial forebulge that formed as a result of upper mantle flow in response to the expansion of the Laurentide ice sheet during glacial periods.

A previous review [9] summarized literature focused on the Bermuda area and the NE coast of the USA. The authors also published the results of a new stalactite sampled in a cave at $+1.5 \mathrm{~m}$ asl in the age range from $137 \mathrm{ka}$ to $71 \mathrm{ka}$. Four hiatuses are clearly visible in a continuous deposition on the speleothem (Table 1). A first hiatus (MIS 5.5) occurs from $137.0 \mathrm{ka}$ to $114.7 \mathrm{ka}$, and a second from $105.9 \mathrm{ka}$ to $92.0 \mathrm{ka}$ corresponds with MIS5.3. The third hiatus ranges from $84.3 \mathrm{ka}$ to $82.0 \mathrm{ka}$ and corresponds with MIS5.1, and the presence of an additional hiatus from $79.9 \mathrm{ka}$ to $75.0 \mathrm{ka}$ corresponds with MIS5.1bis.

U-Th age uncertainties range between $\pm 7 \mathrm{ka}$ and $\pm 1 \mathrm{ka}$. These data support previous controversial indications that Bermudian RSL was significantly higher than the RSL at other locations during MIS5.5 and MIS 5.3 (Figure 2, Table 1).

Andros Island (The Bahamas)

A previous study [4] examined 116 speleothems that were collected from 22 caves that are part of a wide cave system in Andros Island (The Bahamas) during several expeditions from 1984 to 1992 (Figures 2 and 7).

Table 1 reports the results of one of the most interesting speleothems collected at $-18.1 \mathrm{~m}$ and covering almost the entire glacial period. The speleothem was sampled from $-53.6 \mathrm{~m}$ and $-1813.8 \mathrm{~m}$. Regarding the flowstone sequence, which was called GB-89-25-5A/ B / C, at $-18.1 \mathrm{~m}$ bsl (Table 1, Figures 1 and 2) the authors stated that other samples grew continuously throughout this period. "We cannot, therefore, support the suggestions for high sea-stand events near present sea level between 93 and $15 \mathrm{ky}$ ". The same speleothem shows a non-erosional hiatus between $63.7 \pm 1.7 \mathrm{ky}$ and $58.5 \pm 0.7 \mathrm{ky}$ corresponding to MIS3 (Table 1, Figure 6).

\subsubsection{Lucayan Cavern DWBAH Flowstone (The Bahamas)}

The Lucayan Cavern DWBAH flowstone can be considered a historical discovery. The results of the work were published in 1989 using precise U-Th TIMS dating [3]. After 32 years, it remains one of the most complete sequences. The flowstone started to form about $300 \mathrm{ky}$ ago at $-10 \mathrm{~m}$ and ceased its growth about $39 \mathrm{ky}$ ago. The flowstone shows five hiatuses in accordance with MIS9, MIS7.5, MIS7.3, MIS5.5, and MIS5.3 [3,5]. The tectonic rate considered for The Bahamas area is $1 \mathrm{~m}$ every $50 \mathrm{ky}$, as suggested by [7] (Table 1, Figures 2 and 7). 


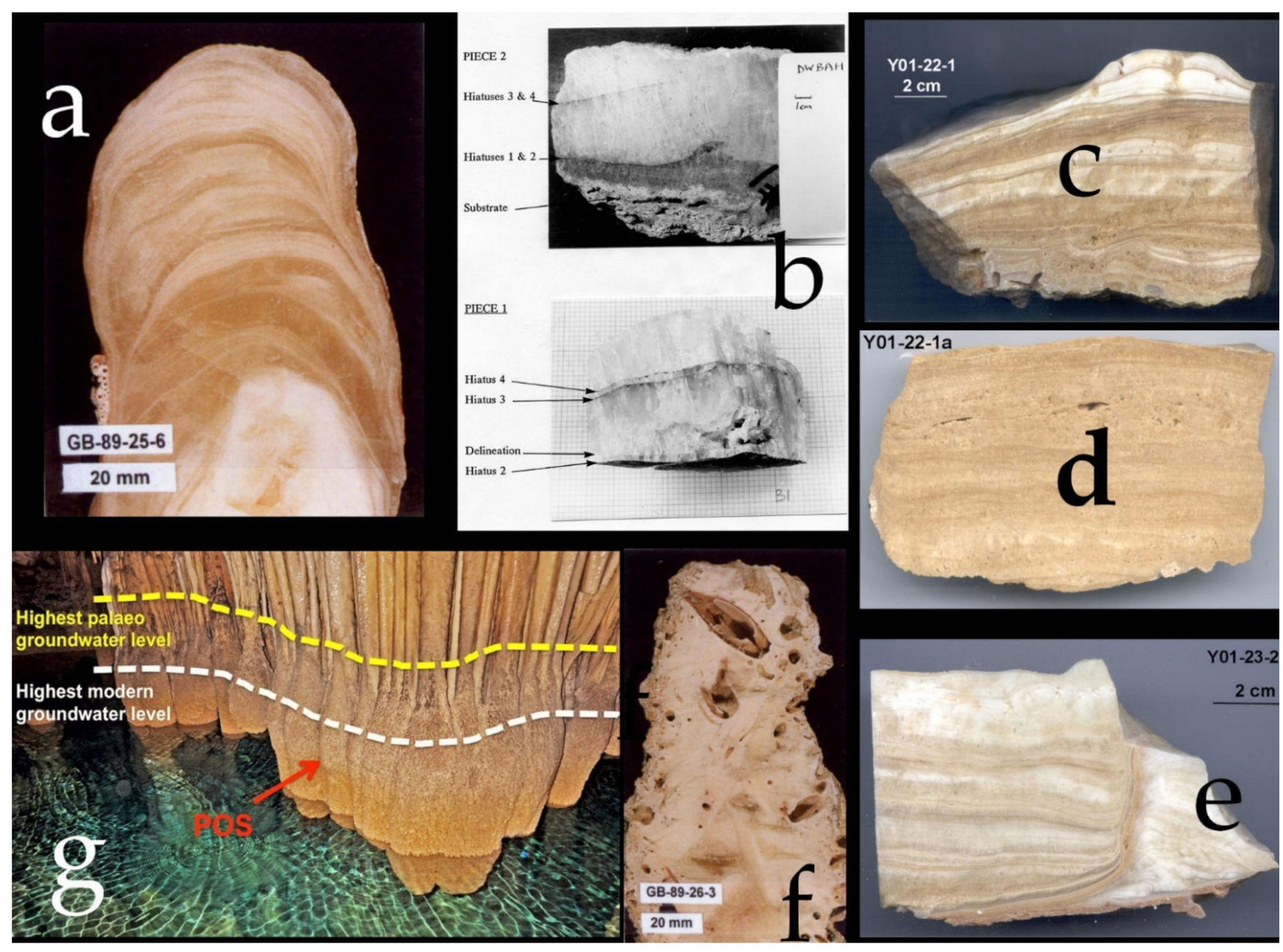

Figure 7. Submerged speleothems from the Caribbean. (a) Bahamas Blue hole, South Andros, Scheme 89. partially covered by serpulid overgrowths, $-13.8 \mathrm{~m}$, Lucayan cavern (courtesy of David Richards). (b) The DWBAH flowstone, sampled at $-15 \mathrm{~m}$ in the Grand Bahama Island (courtesy of Joyce Lundberg). (c,d) Flowstone Y01-22-1, Y01-22-1a, -9.9, Yucatán (courtesy of Gina Moseley). (e) Flowstone Y01-23-2, -4.9, Yucatán (courtesy of Gina Moseley). (f) Bahamas Blue hole, South Andros., stalagmite GB-89-26-3 a stalagmite bored by Lithophaga (courtesy of David Richards). (g) Japan, phreatic speleothem at Minaido Daito island (courtesy of Blaz Miklavic).

\subsubsection{Santa Catalina Cave (Cuba)}

The Santa Catalina cave is carved into a marine terrace, which occurs along the Cuban coast. It was suggested by [19] that a general slowly uplifting trend occurred during the Pleistocene, even if U-Th dating of these terraces is difficult to achieve considering local conditions. The minimum age of the terraces can be constrained by dating carried out on speleothems from coastal mixing (flank margin) caves formed during past sealevel highstands together with the carving of marine limestones (Table 1, Figure 2). The authors suggested that speleothems collected in the Santa Catalina cave (Matanzas) provided ages $>360 \mathrm{ky}$ and showed several cycles of subaerial and subaqueous corrosion and speleothem growth. This suggests that the cave was carved during the MIS 11 sea-level highstand or earlier. Some stalagmites grew from MIS 11 to MIS 8 and were submerged twice, once at the end of MIS 11 and again during MIS 9. Phreatic overgrowths (POS) covering the speleothems suggest the presence of anchialine conditions within the cave during MIS 5.5. The altitude of these speleothems $(16 \mathrm{~m}$ asl) indicates a late Pleistocene uplift rate of less than $0.1 \mathrm{~mm} \mathrm{ky}^{-1}$. 


\subsubsection{Yucatán}

A previous study [11] found and dated four marine levels between 8.9, 8.6, $8.46 \mathrm{ka}$ cal BP that were collected on a stalactite sampled at $-6 \mathrm{~m}$ in a cenote on the Yucatán Peninsula. The authors interpreted dated levels as sea-level fluctuations: "therefore, it seems highly likely that four relative sea-level oscillation events are responsible for submergence and re-emergence. These oscillations are presumably due to GIA movements since all the area is considered tectonically stable". The authors also discussed the results obtained by [78] on the U-Th ages from the Acropora palmata fossil corals and suggested that the error related to the paleoposition of the sea level can reach $10 \mathrm{~m}$, while a submerged speleothem with marine layers gives error bars of $\mathrm{cm}$, especially considering the local microtidal amplitude of $0.3 \mathrm{~m}$ (Table 1, Figure 2).

Another study [10] provided an age for numerous speleothems sampled in different submerged caves and cenotes in the Tulum area (Table 1, Figures 2 and 7) at $-14.6,-11$, -9.9 and $-4.9 \mathrm{~m}$. The results (summarized in Table 1) indicated that between $109 \mathrm{ky}$ and $61 \mathrm{ky}$ ago the highstand of MIS $5.1 \mathrm{did}$ not reach the lowest altitude of the speleothems studied $(-14.9 \mathrm{~m} \mathrm{bsl})$. With regard to the MIS 5.3 highstand, it did not reach an altitude of $-11 \mathrm{~m}$ bsl. For MIS 5.5, the precise speleothem age measured at $-4.9 \mathrm{~m}$ bsl provides a robust chronology for the timing of the fall at the last interglacial termination, or the 5.5-5.4 transition.

\subsubsection{Minami Daito Island (Japan)}

A previous study [13] researched the partially flooded Akiba Chiteiko cave, in a small atoll in the northern Philippine Sea (Figure 3). The sample shows a phreatic overgrowth on speleothem (POS). Sampling and dating the highest POS level, which corresponds to the high tide mean level (Figure 7), the authors suggest that the sea level reached its Holocene maximum highstand between 5.1 and $4.6 \mathrm{ka}$ cal BP, after which it remained more or less stable until the present day, with a possible minor sea-level drawdown of about $35 \mathrm{~cm}$. The sea level at Minami Daito did not have a distinct highstand in the Holocene, which coincides with the mid-Holocene maximum observed elsewhere in the Indo-Pacific basin.

\subsection{New Data}

\subsubsection{Favignana Island}

We sampled and analyzed a speleothem with continental, marine and phreatic layers from a small cave at Favignana Island (Egadi Archipelago, Sicily) (Figures 4 and 5). The cave entrance is narrow, with a length of $14 \mathrm{~m}$, an average width of about 3-4 m, and a depth of about $7 \mathrm{~m}$ at the entrance that reduces to about $4 \mathrm{~m}$ inside (Figure 8). The studied speleothem, more precisely a stalactite, was blade-shaped with a width of about $1 \mathrm{~m}$ and was collected at the bottom of the cave. Today, the cave is flooded and the sea level lies $0.35 \mathrm{~m}$ above the speleothem (Table 4 ).

The speleothem shows an emerged part made of brown colored subaerial carbonate facies, and a $6 \mathrm{~cm}$ white carbonate facies that suggests a phreatic genesis. Between the aforementioned facies, we also noted and analyzed (Figure 4) a marine overgrowth made up of serpulids. Radiocarbon ages of subaerial carbonate overgrowth provided an age of $23.9 \mathrm{ky}$ cal BP, while the marine overgrowth of $1.3 \mathrm{ky} \mathrm{cal} \mathrm{BP}$ and the last presently submerged phreatic layer provided an age of $0.7 \mathrm{ky} \mathrm{cal} \mathrm{BP.}$

\subsubsection{Ustica}

The submerged cave (location and sketches in Figure 5) has a small entrance at $-13 \mathrm{~m}$ bsl. A $10 \mathrm{~m} \times 10 \mathrm{~m}$ room with open-air at sea level was found inward. The cave roof was estimated to be about $2 \mathrm{~m}$ in height asl. Hundreds of stalactites hang from the vault of the cave, all formed only of continental carbonate. There are also some plant roots. In the submerged portion, both on the cave walls and the submerged stalagmites and stalactites, Polychaeta overgrowths can be observed. In some cases, they appear to be very large (up to $7-8 \mathrm{~mm}$ in diameter; see Figure 4 ). The stalactite sampled around the present-day sea 
level was covered with living Polychaeta. Once dissected, it showed a dark brown central part due to continental/phreatic deposition that occurred in the subaerial environment (Figure 4). Microscope analysis showed that the external part of the speleothem, which had lighter tones, presents a mix of both marine (with polychaetes) and continental origin (Figure 5). The age of this stalactite was estimated to be about $1000 \mathrm{y}$ (Table 2). Radiocarbon dating carried out on the outermost part of the speleothem showed an older age while maintaining a stratigraphically correct sequence (Table 3).

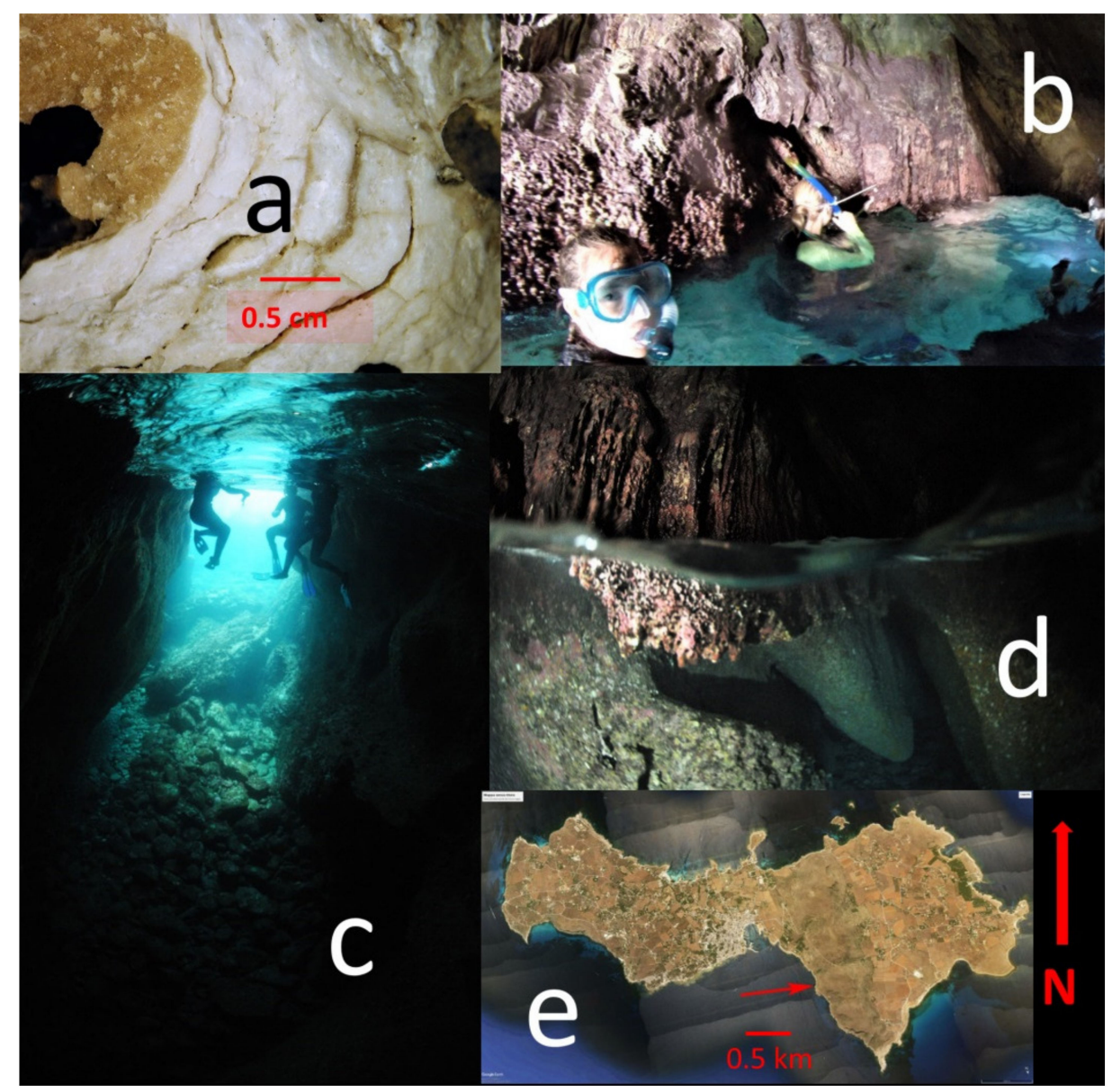

Figure 8. Coastal cave and submerged speleothems at Favignana Island, Italy (Figures 1 and 4; Tables 2 and 3). (a) Section of stalactite sampled at $-0.32 \mathrm{~m}$ with the continental portion (brown) and the phreatic portion (white). (b) Sampling survey at the bottom of the cave. (c) Photo of the cave. (d) The appearance of the freshly sampled stalactite. (e) Favignana and the site of the Stalattiti Cave.

\subsection{GIA Numerical Predictions}

For the three ice-sheet models, the predicted RSL curves computed at each location and for each of the four mantle profiles tend to be distributed above the eustatic curves, with Japan being the only exception, as it is almost always below the eustatic curve throughout the last $250 \mathrm{ka}$ (Figure 9a-c). The Mediterranean sites (Ustica and Favignana islands) are very close to the eustatic component and do not show significant variability as a function of mantle viscosity profiles. The same holds for Japan, where local RSL variability is larger for ICE-5g and ICE-6g and negligible for ANICE-SELEN. In the Caribbean and Yucatán, the local RSL variability was in the order of 20-30 m during glacials and interstadials, and decreased during the MIS 5.5. This implies that Bermuda and The Bahamas, being closer to the North American ice-sheet margins, are more sensitive to GIA-modulated vertical motions, which can be emphasized by specific viscosity profiles. 

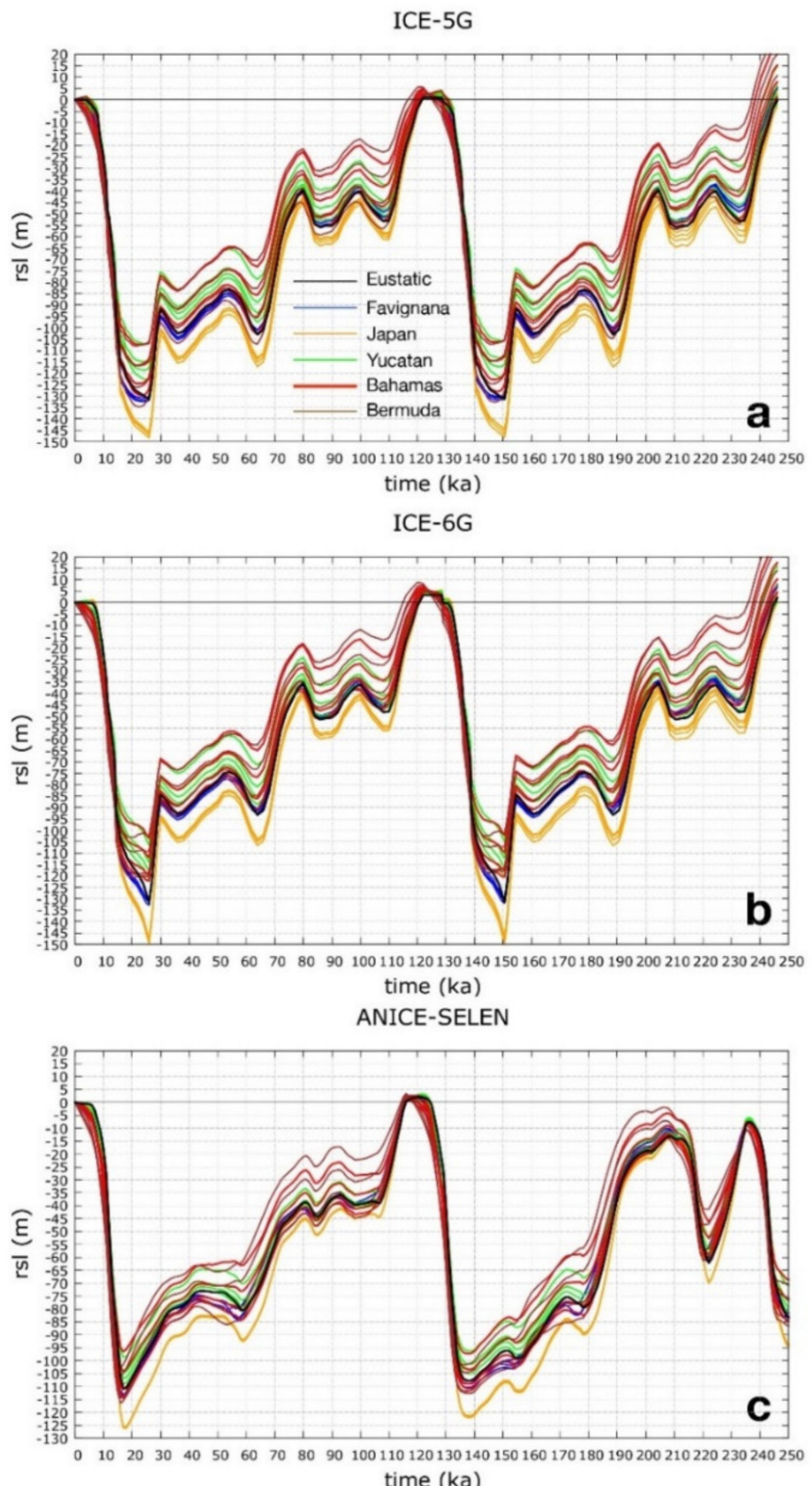

Figure 9. Cumulative predicted RSL curves for ICE-5G (a), ICE-6G (b), and ANICE-SELEN (c) icesheet models in combination with different mantle viscosity profiles (see legend and Tables 5 and 6 for details). The black curves represent the eustatic sea-level variation for each ice-sheet model. The colored curves represent the RSL change for each site under consideration.

RSL Predictions vs. Observed Values (MIS 5.1-5.3)

Overall, the predicted RSL peaks are lower than the observed terrestrial limiting elevations (deposition) and the hiatuses and the marine transgressions inferred from the speleothems (Figure 10). The largest RSL variability was predicted at Bermuda (Figures 9 and 10c) because of the relative proximity to the ice-sheet margins and peripheral forebulge. Here, the maximum predicted highstands at MIS 5.1 and MIS 5.3 are $\approx 20$ and $\approx 15 \mathrm{~m}$ lower than the speleothem elevation, respectively. Furthermore, the predicted highstands at MIS 5.1 and 5.3 were $\approx 5$ and $\approx 13 \mathrm{~m}$ higher than at Yucatán (Figure 10b). These differences are in line with the results of [9], albeit significantly smaller. We argue that this might be related to the very different ice-sheet models (ICE-1 and ICE-2) used 
by [9]. Moreover, our predictions at Bermuda are only slightly higher than at The Bahamas (Figure 10d), implying that both sites share the same GIA response for the three ice-sheet models and four mantle viscosity profiles.
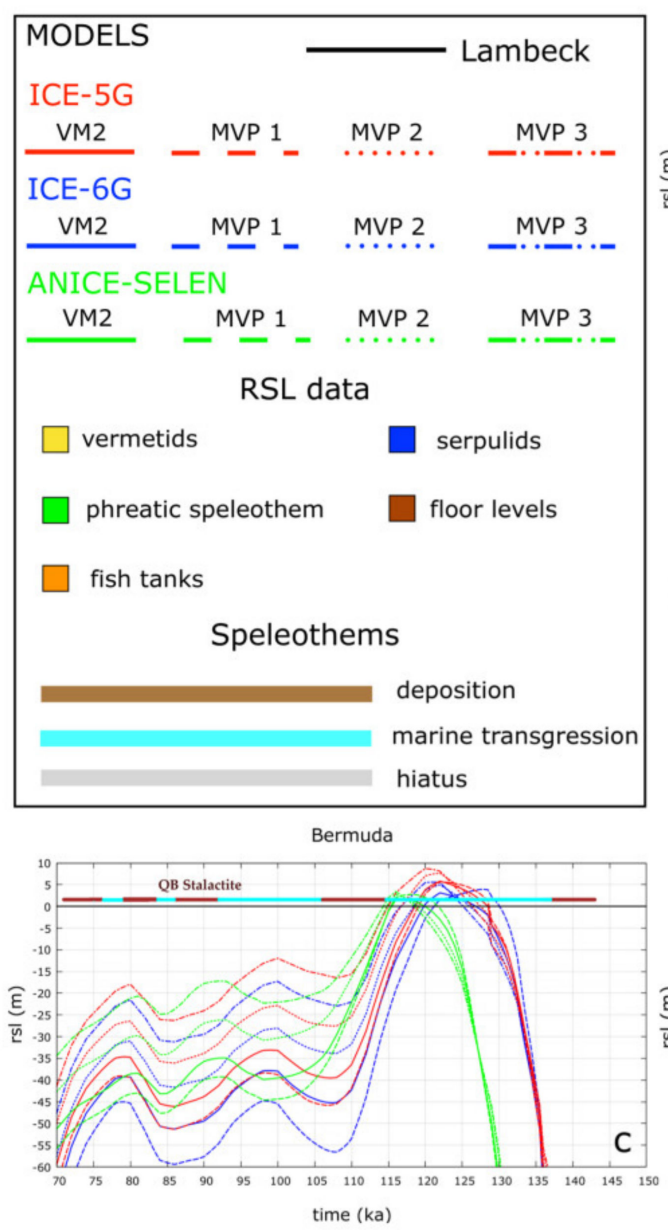
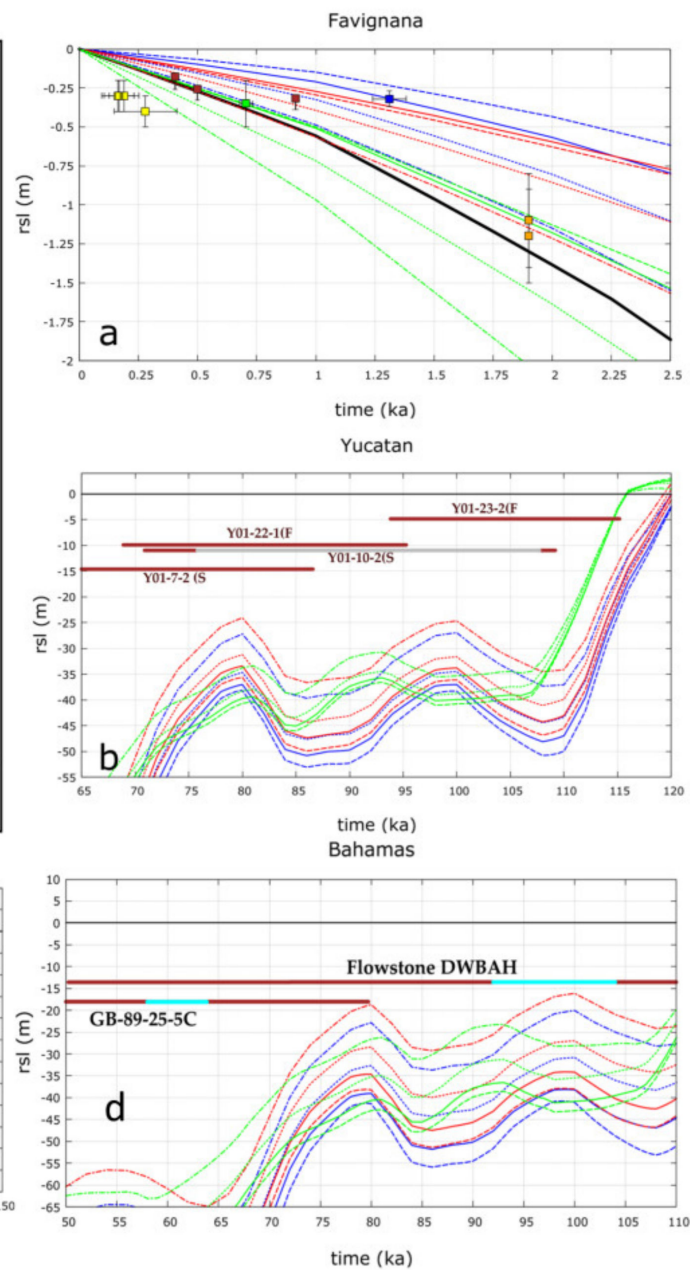

Figure 10. Predicted RSL curves for the ICE-5G (red curves), ICE-6G (green curves), and ANICESELEN (blue curves) ice-sheet models in combination with MVP 1-3 mantle viscosity profiles (solid, dashed and dotted lines, respectively) at each site and with respect to the measured elevations. (a) Favignana. (b) Yucatán. (c) Bermuda. (d) The Bahamas.

\section{Discussion}

Considering the data reviewed in this paper and [6], the use of submerged speleothems appears to provide remarkable results for the global sea-level change history during the Holocene and for long-term sea-level change reconstruction during the Late to Middle Pleistocene, in particular for MIS 1, 3, 5.1, 5.3, 7.1, 7.2, 7.3 7.5, and 9 highstands (Tables 1-4). Figures 11 and 12 depict the results for submerged speleothems from the Caribbean and Japan, and some of the main results of the aforementioned review for the Mediterranean area [6] are compared with the global curve of [79]. In [6], a speleothem sampled in Italy (Custonaci) exhibited marine and continental levels and seems to be older, aged at MIS 25-37 (1.4 MA). 


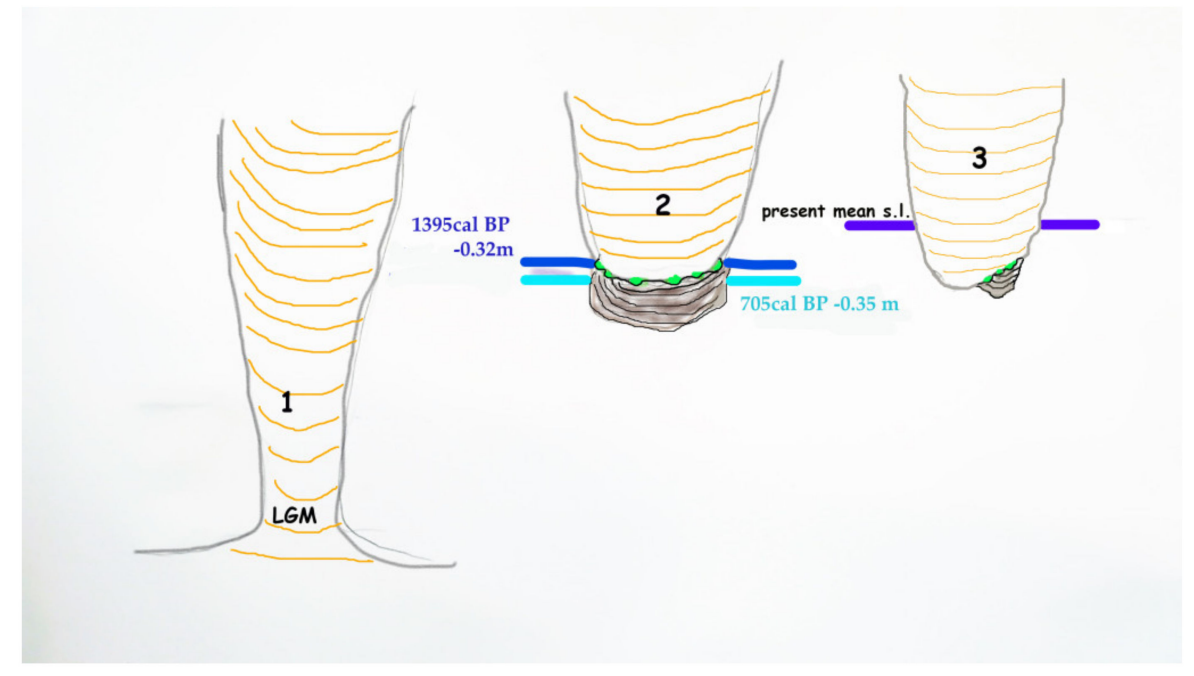

Figure 11. Evolution of the speleothem sampled in the stalactite cave on Favignana. (1) Continental deposition during the last glacial maximum. (2) The sea level was $0.35 \mathrm{~m}$ lower during serpulid overgrowth. (3) Present-day conditions.

\section{Favignana}

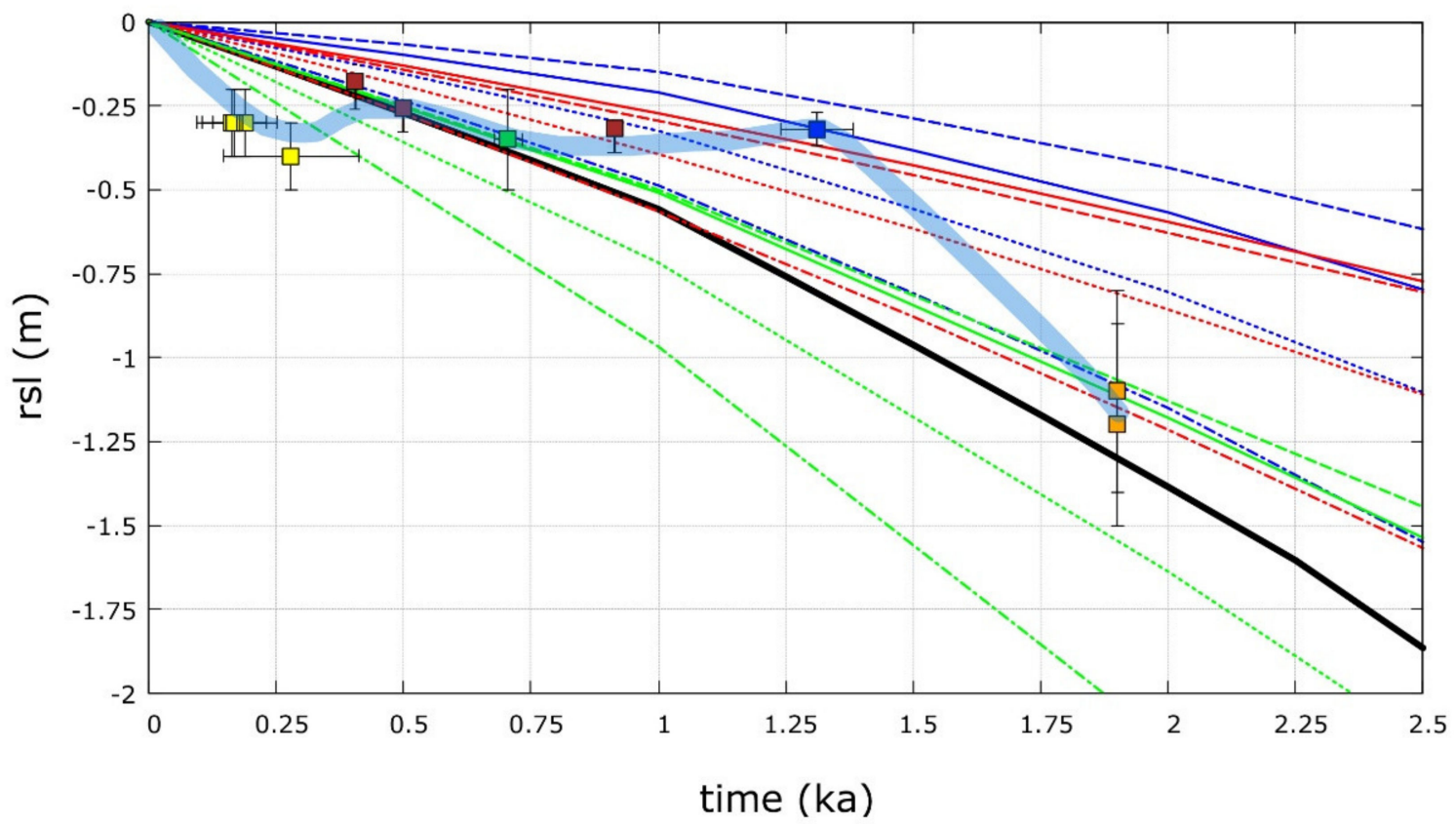

Figure 12. Relative sea-level history over previous $2 \mathrm{ka}$ BP estimated using the phreatic speleothem (blue square) and serpulids overgrowth (green square) at Favignana compared with (1) different sea ice models (see caption of Figure 11 for ice model); (2) a 2 kyr fish tank form Sorrento (Aucelli et al., 2017, light brown squares); (3) arcaheological markers (brown squares) from the S. Nicola cathedral (Pagliarulo et al., 2013); (4) Vermetid reef (yellow square) from S.Vito lo Capo (see Table 4). The sea-level change (blue) curve intercepts the Warm Medioeval Period and the Little Ice Age.

\subsection{Favignana Stalactite}

The Favignana speleothem provides an interesting result concerning sea-level change over the last 1300 years, as sea-level data are very scarce in tectonically stable areas of the Mediterranean Sea $[80,81]$. The submerged portion of the stalactite was truncated and bored by Lithophaga lithophaga. The cave (Figure 8 ) may have recently been enlarged by marine processes, such as storm waves, a hypothesis that is supported by the fact that 
almost all the other stalactites near the one we studied were truncated. Based on this, we hypothesize the following evolution:

(1) During LGM, the sea level was far from Favignana, at about $-129 \mathrm{~m}$ bsl [82], and the speleothem presumably formed a column (Figure 11) aged $23.9 \mathrm{ka}$ BP (Table 3).

(2) The sea level rose until 1395 years cal BP. The sea level stillstand at $-0.32 \mathrm{~m}$ promoted the growth of colonies of serpulids and sponges that formed on the broken surface of the speleothem, as reported from the Argentarola cave by [38,83].

(3) The millimetric layer of phreatic carbonate (Figure 11) shows that the aforementioned sea-level stillstand was up to $-0.35 \mathrm{~m}$, considering the deeper phreatic level. Radiocarbon dating of the most recent level is $705 \mathrm{ky} \mathrm{cal} \mathrm{BP} \mathrm{(Table} \mathrm{3).}$

(4) The phreatic level was then interrupted by marine ingression, so that the submerged part of the stalactite was bored by Lithophaga sp., while the external carbonate surface of the submerged part of the speleothem was colonized by small serpulids, tetracorals, limpets, and sponges.

The levels of phreatic carbonates have been used in the Mediterranean as sea-level markers by $[28,30]$. In our case, the entire phreatic formation has not been preserved, but only some non-eroded fragments were observed. For this reason, we hypothesize (similar to the cave from Palma de Mallorca) that the thickness of the phreatic deposit (in the shape of a ball) is on average as high as the average tide of Favignana (annual mean: $32 \mathrm{~cm}$, OSU tidal prediction model, http:/ / volkov.oce.orst.edu/tides/otps.html), and that it has a greater thickness in the depth of the phreatic, the speleothem was sampled on 23 September 2014.

In addition, the age correction due to dead carbon was not difficult in this case. It showed that the value of the term DCP is known. In the case of the Favignana stalactite, the age of $806 \mathrm{yr}$ BP (calibrated 705 cal yr BP, sample S3) would become $478 \mathrm{yr}$ BP (calibrated to 518 cal yr BP) with a dead carbon percentage of $4 \%$. Even a DCP of $10 \%$ would be enough to make the sample modern. In other words, if the DCP percentage of "dead" carbon in the cave was $10 \%$, the sample would correspond to the present day. This is obviously not reasonable, especially because the stalactite was submerged. This suggests that the effect of dead carbon is very low, or negligible, in the studied cave. The dating of $705 \mathrm{yr}$ BP, without considering dead carbon effects, fits perfectly with the curve, and this cannot be considered a coincidence. The dating analysis therefore leads us to believe that this effect is completely negligible. Figure 12 shows the estimated stalactite age according to different ice models for Favignana (see caption from Figure 10 for ice model, and Table 3) and other geomorphological and geoarchaeological markers of the same time range are compared. The serpulids overgrowth dated back to 1395 cal BP and was above almost all other curves. The phreatic speleothem dated back to 705 years and was in agreement with the average of the other curves. We also added some archaeological and biological markers in the $2 \mathrm{ka}$ time range (Figure 12). For example, a fish tank in Salerno at $-1.4 \mathrm{~m}$ bsl was dated back to $1.9 \mathrm{ky}$ in [84]. At about $-0.40 \mathrm{~m}$, we found a less precise marker (a walking surface of the basilica of San Nicola [81]) at $-0.32 \mathrm{~m}$ in the Middle Ages. We also added some radiocarbon ages from Vermetid reefs [65] at $-0.3 \mathrm{~m}$, which dated back to 169, 163,189 years cal BP, and another at $-0.4 \mathrm{~cm}$ which dated back to 279 years cal BP. Even if we advance these hypotheses with few data, there appears to be a peak of the sea-level curve that corresponds with the Medieval Warm Period between 900 and 1200 y AD and a cooling corresponding with the Little Ice Age between 1550 and 1900 y AD. This trend is in agreement with what was found by a study in Israel [80].

\subsection{Ustica Stalactite}

The stalactite sampled at the present-day sea level was about $0.8 \mathrm{~cm}$ long, with a diameter ranging from 4 to $8 \mathrm{~cm}$ (Figure 4c). As shown in Tables 2 and 3, this speleothem covers a very narrow time range of about 900 to 1000 years (Figure 4a). There is a high concretion rate, which is somewhat surprising, given that it is located in a volcanic area. However, the Ustica lava contains many fragments of carbonate platform that erupted 
together with the lava, and these carbonate outcrops are often found within lava outcrops of up to $30 \mathrm{~m}$, in some cases also with a modern tidal notch [51]. The most recent portion of the speleothem was formed by large living serpulid tubes. In the portion between the continental part and the living polychaete worms, continental sediment showing a different color was observed (Figure $4 \mathrm{~b}$ ) together with porosity and polychaete tubes, and sponges incorporated in the sediment were clearly visible.

The mixed deposition of continental carbonate with serpulid tubes (Figure 5b) constitutes a clear signal of positive and negative vertical coseismic movements. The radiocarbon age of this outer portion shows older values, albeit in perfect stratigraphic order, with respect to the central part (Figure 5a) of the satalactite aged with U-Th. The final part is younger. Our explanation for this is that the dead carbon of the very ancient carbonate inclusions in the Ustica lava has altered the date but not the stratigraphic order. The average tide amplitude in Ustica of $36 \mathrm{~cm}$ (https:/ / www.tide-forecast.com/) and the length of the sampled (on 17 september 2016) speleothem (on of about $85 \mathrm{~cm}$ (Figure 4c) provide further evidence that, over the last $1 \mathrm{ka}$, the island of Ustica was affected by positive and negative coseismic events. This consideration is confirmed by the very recent coseismic movement described at the nearby Grotta Segreta, with a coseismic uplift of $0.4 \mathrm{~m}$ due to the 1906 earthquake [51]. The studied stalactite indicates both positive and negative vertical movements, with a positive average component (uplift) that can be deduced from the altitude of the MIS 5.5 deposits containing Persistrombus latus at $35 \mathrm{~m}$ altitude [52], and by the presence of marine terraces raised on the lava, with an uplift rate ranging from 0.13 to $0.24 \mathrm{~mm} \mathrm{yr}^{-1}$ (see also Figure 5) [53].

\subsection{Speleothems from the Caribbean and Japan}

U-Th dating of the speleothems sampled at Bermuda, The Bahamas and Yucatán caves (Figure 2, Table 1) provided detailed information on the timing, duration, and altitude of sea-level highstands during the late and middle Pleistocene.

\subsubsection{MIS 2-Holocene}

A previous study analyzed a peculiar speleothem that preserves four marine hiatuses between 10.9 and $58 \mathrm{ky}$ cal BP [11]. The region where this occurred is considered to be tectonically stable and it is unlikely that GIA could have been responsible for these anomalous crustal and/or sea surface fluctuations.

Another study [13] focused on a cave on the island of Minami Daito in Japan, which was made of a phreatic overgrowth. The authors investigated the relationship between the highest POS level, which represents the maximum elevation reached by the paleogroundwater level and the observed modern highest peak. Regardless of a relevant local mean tide fluctuation of $1.5 \mathrm{~m}$, the authors found that at between 5.4 and $4.6 \mathrm{cal} \mathrm{BP}$, the local sea level reached a maximum highstand of about $35 \mathrm{~cm}$ during the mid-Holocene. This can be explained by GIA-driven ocean syphoning.

\subsubsection{MIS 3}

Figures 13 and 14 show that the GB-89-25-5c speleothem that was sampled at an elevation of $-18.1 \mathrm{~m}$ bsl in The Bahamas [4] had a hiatus between $63.7 \pm 1.7 \mathrm{kyrs}$ and $58.5 \pm 0.7$ kyrs (MIS 3.5, Table 1, Figure 6). The lack of RSL data related to MIS 3.3 (and MIS 3 in general) makes this a unique and important indicator from an almost tectonically stable area. Figure 13 shows that the global sea-level curve from [79] is characterized by a much lower highstand of $-48 \mathrm{~m}$ bsl.

Our GIA predictions for the three ice-sheet models and mantle viscosity profiles are characterized by lower RSL peaks at MIS 3 (Figure 9a-c). As the three ice-sheet models are all somehow tuned to the $\delta^{18} \mathrm{O}$ stack curve, we suggest that their volumes might be biased towards larger values, while the speleothems described here might require a volume reduction throughout the MIS 3, which would result in a much higher eustatic level. Interestingly, this is supported by the ice-sheet model reconstruction from [85], 
which, for the MIS 3, provides a eustatic peak of $28 \mathrm{~m}$ bsl. The authors used ice proximal glaciological and geological evidence to constrain the maximum extent of ice sheets through time and reconstruct the ice thickness by modelling the 2D ice profiles based on viscoplastic ice rheological flow law and 2D bottom shear stress. The model was therefore fully independent from far-field RSl observations and deep-sea sea-level proxies.

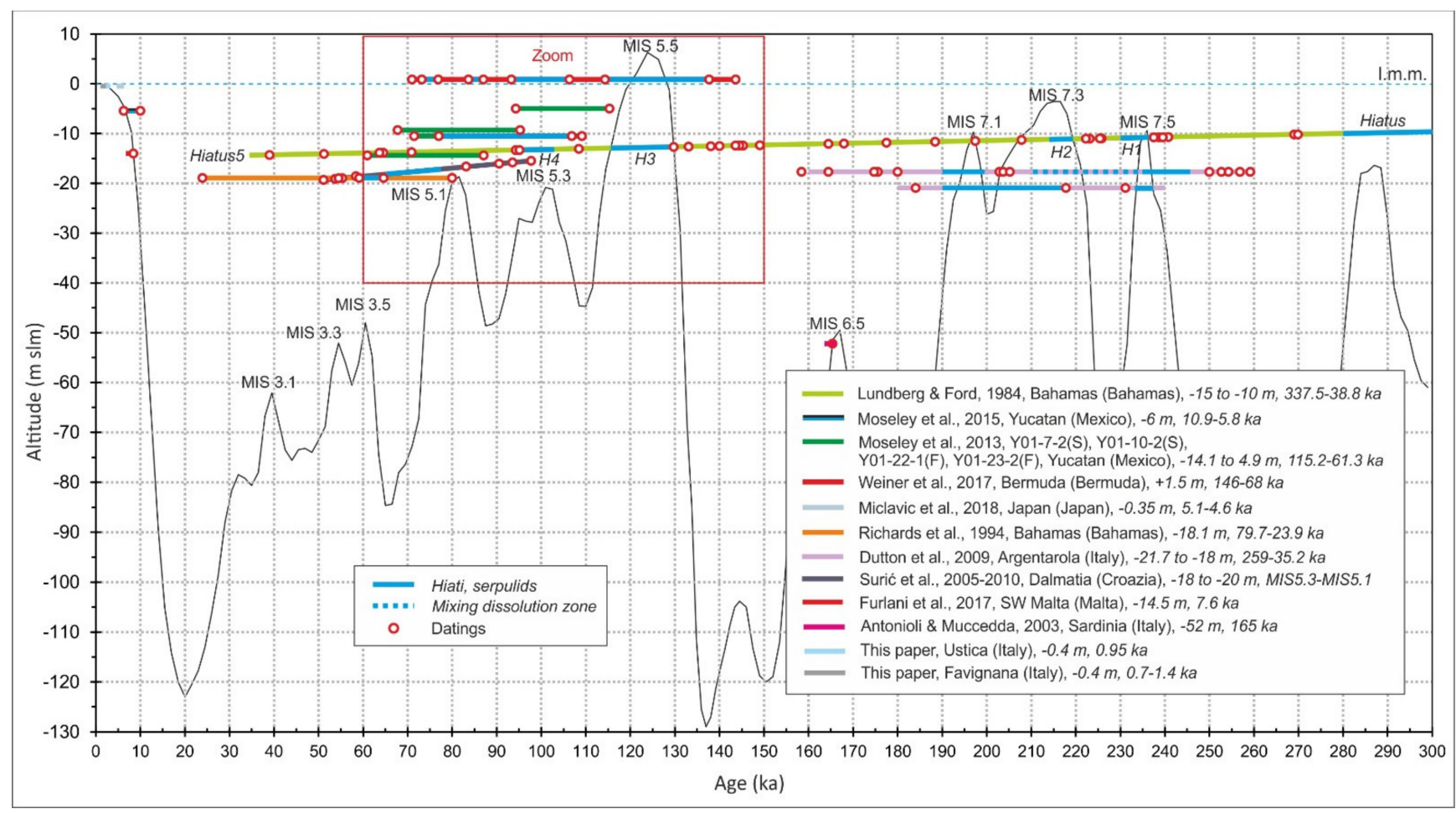

Figure 13. Elevations and radiometric ages (14C and U/Th) of the Caribbean, Japan, and some Mediterranean speleothems discussed in the present study and comparison with the: global sea level curve reconstructed by [79] Black line.

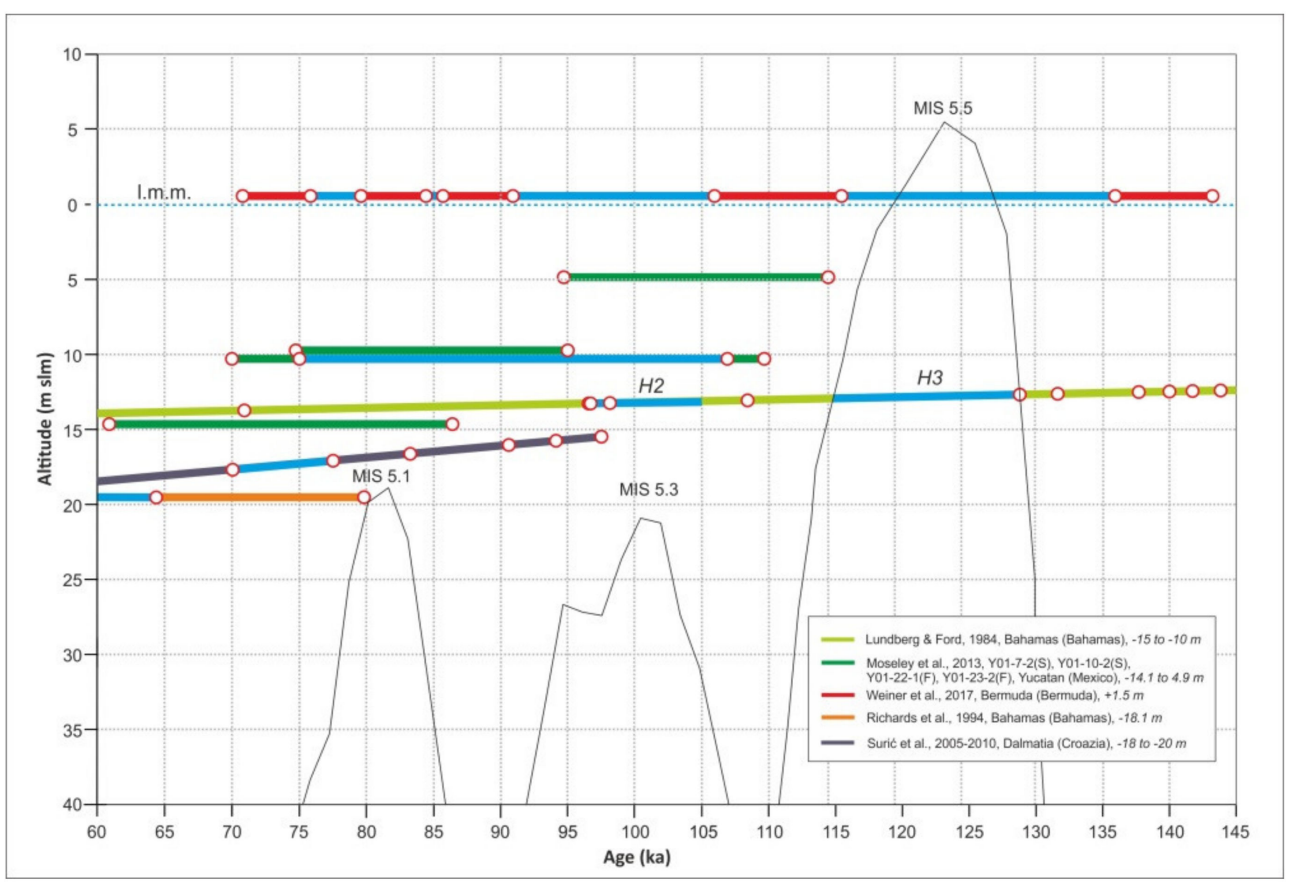

Figure 14. Zoomed in view of part of Figure 13. Fine black line is the global sea-level curve reconstructed by [79]. 


\subsubsection{MIS 5.1}

The Yucatán speleothems do not show any hiatuses during the MIS 5.1 highstand, indicating it did not exceed the elevation of $-14.6 \mathrm{~m}$ bsl [10]. Similarly, the DWBAH flowstone from The Bahamas (corrected for vertical tectonics) does not show any evidence of local sea level higher than $-13.5 \mathrm{~m}$ bsl (Figure 13). Hiatuses are also lacking in the GB89-25-5c speleothem (The Bahamas, [4]), which therefore limits the maximum highstand to $-18.1 \mathrm{~m}$ bsl.

Yucatán and The Bahamas are in an intermediate to far-field position with respect to the ice sheet, where ice-loading-related deformations and ocean syphoning might prevail (Figure 15). Our GIA-modulated RSL curves for Yucatán and The Bahamas (see Figure 10b,d) were lower than the measured elevations, which were also corrected for tectonics. A previous study [9] reported the elevation of the MIS 5.1-5.3 hiatuses at Bermuda, sampled at $+1.5 \mathrm{~m}$ (Table 1), as a consequence of the local GIA. The island, in fact, is considered tectonically stable but very close to the peripheral forebulge that surrounded the North American ice sheet (see Figures 10c and 15). Bermuda, therefore, is significantly affected by the vertical motions of the forebulge, i.e., uplift during ice-sheet expansion and subsidence during ice-sheet retreat (Figure 15).

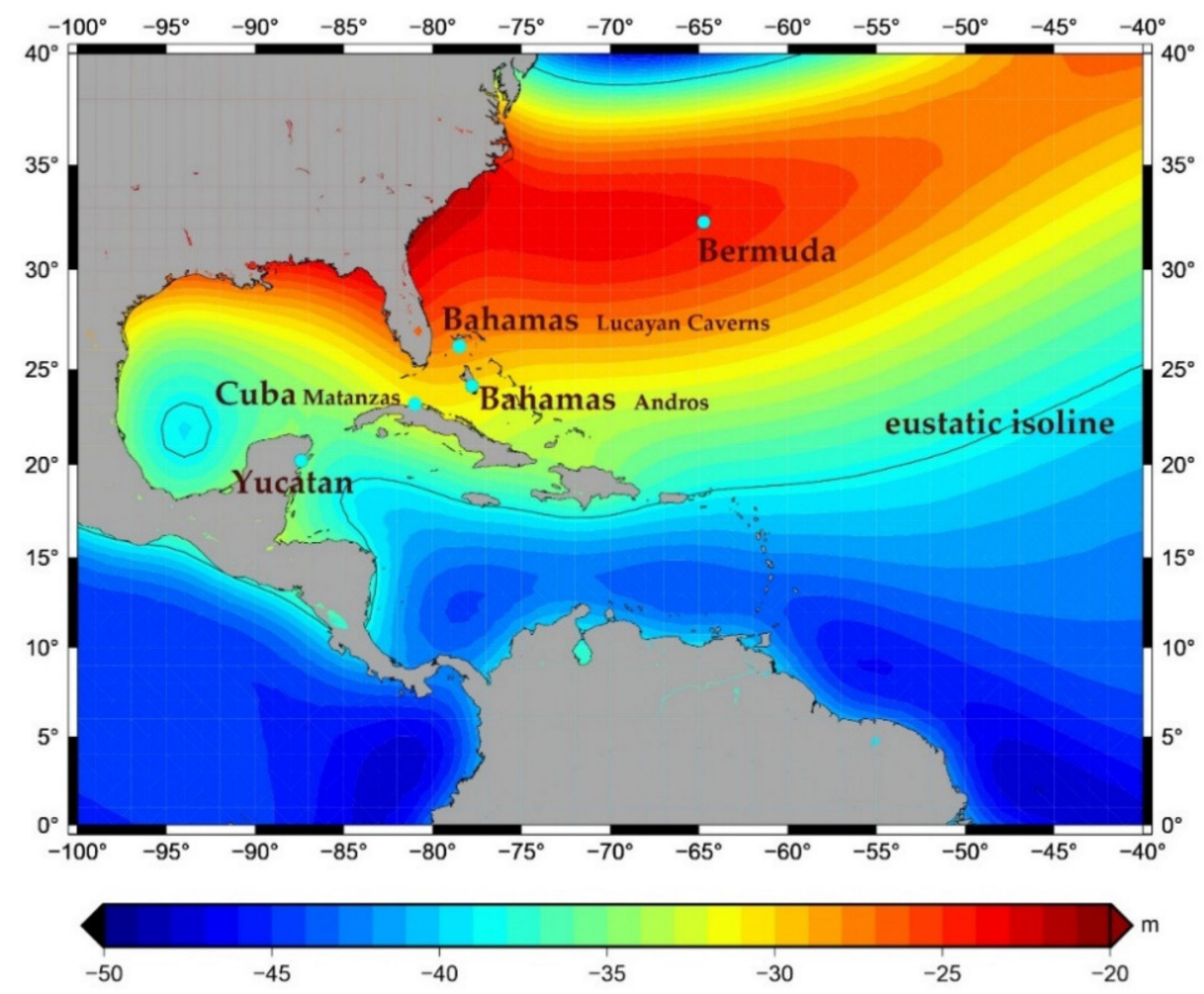

Figure 15. Predicted RSL elevation in the Caribbean Sea during MIS 5.1 according to ANICE-SELEN and the MVP 3 mantle viscosity profile. The light blue dots indicate the location of the sites. The black isoline shows the eustatic value $(-38.5 \mathrm{~m})$.

Our highest MIS 5.1 sea-level prediction in Bermuda reached $-18 \mathrm{~m}$, while lower elevations of -25 and $-20 \mathrm{~m}$ were predicted at Yucatán and The Bahamas, respectively (Figure 10b,d). This confirms that Bermuda is more affected by the GIA-related forebulge processes than Yucatán and The Bahamas (Figure 15).

The elevations inferred from the Caribbean speleothems of The Bahamas and Yucatán $(-13.5$ to $-18.1 \mathrm{~m})$ are somewhat comparable to that observed at the Mediterranean site of the Argentarola cave $(-18.8 \mathrm{~m})[6,86]$. We argue that an elevation of $-19 \mathrm{~m}$ could be representative of the intermediate-field areas such as the Caribbean and the Mediterranean Sea, in agreement with [85]. 
Therefore, by removing the expected GIA contributions, we also hypothesize a eustatic elevation for the MIS 5.1 of approximately $-17 \mathrm{~m}$, obtained as average value between -18.8 and $-13.5 \mathrm{~m}$.

\subsubsection{MIS 5.3}

The speleothem from Bermuda which lies at $+1.5 \mathrm{~m}$ asl preserves several hiatuses and was probably affected by forebulge processes (Figure 9a-c, Figure 10c, and Figure 16).

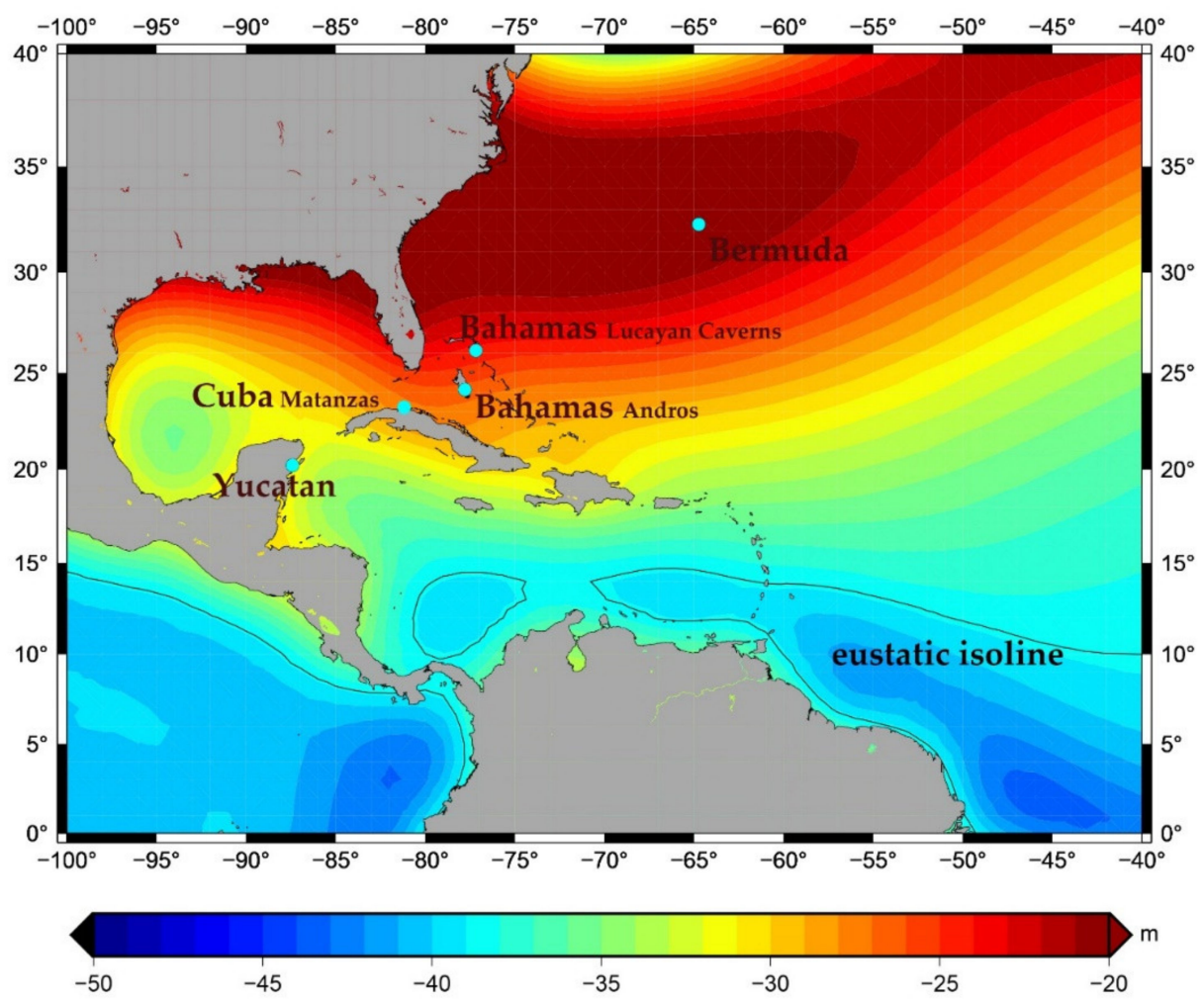

Figure 16. Predicted RSL elevation in the Caribbean Sea during MIS 5.3 according to ANICE-SELEN and the MVP 3 mantle viscosity profile. The light blue dots indicate the location of the sites. The black isoline shows the eustatic value $(-38.81 \mathrm{~m})$.

The DBWAH flowstone from The Bahamas at $-13.0 \mathrm{~m}$ bsl shows an MIS 5.3 hiatus that cannot be explained by our GIA results. A hiatus was recorded in Yucatán, where the sea level might have been higher than $-11 \mathrm{~m}$ after $109 \mathrm{ka}$, but less than $-5 \mathrm{~m}$.

As it occurs with the MIS 5.1 elevations, our GIA predictions for the MIS 5.3 highstand cannot reach the observed elevations (Figure 9a-c, Figure 10a-d). Again, we argue that a reduction of ice-sheet volumes is required to shift the eustatic value upwards.

We suggest a eustatic highstand of between -12 and $-6 \mathrm{~m}$.

\subsubsection{MIS 5.5}

All the submerged speleothems from the Caribbean Sea show hiatuses at $-6 \mathrm{~m}$ bsl at $117 \mathrm{ky}$ (Yucatán), $-18.1 \mathrm{~m}$ bsl at $148 \mathrm{kyrs}$ (The Bahamas), and -14 at 134 kyrs of the flowstone DWBAH. The only difference between these was the timing of the transgression. In Bermuda, the hiatus of MIS 5.5 was between 114 kyrs and 137 kyrs.

\subsubsection{Middle Pleistocene}

The only date that was older than MIS 5.5 was provided by the DWBAH flowstone [3,5], which contained five marine hiatuses (MIS 9, 7.5, 7.3, 5.5, 5.3).

We can provide some considerations on differences in tide amplitude between the Caribbean Sea and MS. Table 1 shows the maximum tide amplitudes in Bermuda and The 
Bahamas of about $1.3 \mathrm{~m}$ and lower than $0.5 \mathrm{~m}$ in the other sites in the MS. Some corals used by some key studies, such as $[87,88]$, used Acropora palmata with a depth range from $-1 \mathrm{~m}$ bsl to $-20 \mathrm{~m}$ bsl (measured on Barbados). We suggest that the precision in elevation of the submerged speleothems is higher than corals, because speleothems are precise indicators with respect to the mean sea level for tides lower than $0.5 \mathrm{~m}$ (Table 1).

\section{Conclusions}

Submerged speleothems can grow for significantly long timespans and, therefore, can record multiple intervals during which deposition stops and/or erosion takes over in response to sea-level highstands. The alternation of continental depositional layers and hiatuses or marine layers records show long-term climate-related global ice-sheet fluctuations. In this review, we show that the use of submerged speleothems significantly contributed to constrain the short-term (Holocene) and long-term (Middle and mostly Late Pleistocene) sea-level changes in the Caribbean, Japan, and the Mediterranean Sea.

The longest time span was recorded in the DWBHA flowstone [3] at The Bahamas and covered the last $326 \mathrm{ka}$, with five hiatuses recorded. The Bahamas speleothem GB-89-25-5 covered the time between 80 and $24 \mathrm{ka}$ and contained one hiatus. At Bermuda, the QB speleothem covered the time between 70 and $146 \mathrm{ka}$ and recorded four hiatuses. Several speleothems from Yucatán [10] cover a time span ranging from 61 to $115 \mathrm{ka}$, with one hiatus. In the Mediterranean Sea, the ASI speleothem from Argentarola [86] covers the last $210 \mathrm{ka}$ and recorded four hiatuses. The K-18 stalactite from Croatia $[6,26]$ spanned 55 to $131 \mathrm{ka}$ and contained one hiatus.

Overall, the discussed speleothems reflect the effects of the regionally varying GIA signal, which is indicated by its RSL fingerprints that stem from ice-sheet configurations and the solid earth response.

Holocene: continental, POS, and marine overgrowth (serpulids) portions from submerged speleothems in Favignana (Mediterranean Sea) facilitate the construction of a sea-level curve for the last 2000 years (Figure 12).

The Yucatán speleothems exhibit four hiatuses between 10.8 and $4.6 \mathrm{ka}$, which suggests high-frequency sea-level fluctuations that might have been superimposed on the local falling sea level in response to the GIA-driven ocean syphoning and continental levering [11].

Similarly, the phreatic speleothem from Minami Daito Island in Japan records a midHolocene sea-level highstand of $0.35 \mathrm{~m}$, which is characteristic of the far-field Asian sites where the ocean syphoning process dominates [13].

MIS 3: the Bahamas elevation was -18.1 , which is much higher than the typical global eustatic curves, but also higher than the observed value from the Mediterranean sites (from -29 to $-19 \mathrm{~m}$ ). This might be due to the different GIA responses of the two regions.

MIS 5.1: the presence or absence of hiatuses in The Bahamas and the Mediterranean speleothems indicate a sea level of between -13.5 and $-19 \mathrm{~m}$. The higher elevation at Bermuda is related to the GIA.

MIS 5.3: the presence or absence of hiatuses suggests a eustatic sea level between -12 and $-6 \mathrm{~m}$. At Bermuda, the MIS 5.3 exceeds the $+1.5 \mathrm{~m}$ of elevation because of local GIA.

MIS 5.5: all the speleothems exhibited hiatuses between 117 and $148 \mathrm{ka}$. In particular, the $-6 \mathrm{~m}$ elevation of the Yucatán speleothem constrains the end of the MIS 5e local highstand. Similarly, the elevations of -18.1 and $-14 \mathrm{~m}$ at 148 and $134 \mathrm{ka}$, respectively, constrained the local RSL rise at The Bahamas before the actual MIS 5e highstand.

The maximum vertical differences between the GIA-modulated MIS 5.5 highstands from the different Caribbean sites were quantified in the order of $\approx 8 \mathrm{~m}$, typical of intermediate-field regions. In the Mediterranean Sea, the vertical differences were less than $2.5 \mathrm{~m}$, indicating that it is an intermediate-to-far-field region [59].

MIS 7.1: the flowstone at $-14 \mathrm{~m}$ did not record any hiatuses, while the three speleothems from the Argentarola cave (Figure 13) showed a clearly visible serpulid overgrowth. 
MIS 7.2: a clear highstand was recorded in the Argentarola cave. The sea level oscillated between -18.5 and $-21 \mathrm{~m}$, similar to the global curve that reaches $-27 \mathrm{~m}$.

MIS 7.3: the Bahamas flowstone at $-14 \mathrm{~m}$ did not exhibit any hiatuses. The Argentarola stalagmite shows marine conditions at $-18.5 \mathrm{~m}$, but the local sea level did not exceed $-18.0 \mathrm{~m}$. Therefore, we argue that the global sea level was between 14 and $18 \mathrm{~m}$ b.m.s.l.

MIS 7.5: the observed highstand in the DWBAH flowstone was certainly higher than $-18 \mathrm{~m}$ and presumably lower than $-12 \mathrm{~m}$ and is therefore in agreement with the global curve.

We show that the GIA-driven RSL variability at the sites under consideration increased during interstadial and glacial periods. We argue that this stems from the contribution of the ice-loading-induced crustal and geoidal deformations, which maintain strong spatial RSL gradients.

Author Contributions: Conceptualization, F.A., P.M., P.S.; methodology, P.M., P.S., S.F., E.P.-B.; formal analysis, G.Q., L.C., P.M., E.P.-B.; investigation, F.A., S.F., V.L.P., V.V., J.C., M.G.M.; writing—original draft preparation, F.A., P.S., P.M.; F.F.M., M.G.M.; writing—review and editing, S.F., P.M., P.S. All authors have read and agreed to the published version of the manuscript.

Funding: This research received no external funding.

Acknowledgments: We thank Joyce Lundberg, Yusuke Yokoyama, Blaz Miklavic, Gina Moseley, and David Richards for providing photos; MPA Isole Egadi and Alice Busetti for their help sampling the speleothem at Favignana; MPA Ustica and Salvatore Livreri Console. We also thank the University of Trieste-University funding for scientific research projects-FRA 2018, Stefano Furlani.

Conflicts of Interest: The authors declare no conflict of interest.

$\begin{array}{ll}\text { Abbreviations } \\ \text { MIS } & \text { Marine Isotope Stage } \\ \text { POS } & \text { Phreatic Overgrowth on Speleothems } \\ \text { MS } & \text { Mediterranean Sea } \\ \text { BSL } & \text { Below sea level } \\ \text { MSL } & \text { Mean Sea Level } \\ \text { AMS } & \text { Accelerator Mass Spectrometry } \\ \text { GIA } & \text { Glacial-and Hydro-Isostatic Adjustment } \\ \text { RSL } & \text { Relative Sea Level } \\ \text { SLE } & \text { Sea Level Equation } \\ \text { UM } & \text { Upper Mantle } \\ \text { LUM } & \text { Lower Upper Mantle } \\ \text { TZ } & \text { Transition Zone } \\ \text { LM } & \text { Lower Mantle } \\ \text { BP } & \text { Before Present } \\ \text { AD } & \text { Anno Domini } \\ \text { DCP } & \text { Dead Carbon Percentage } \\ \text { MPA } & \text { Marine Protected Area } \\ \text { DWBAH } & \text { Is the acronym of a submerged flowstone } \\ \text { QB } & \text { Is the acronym of a submerged stalagmite }\end{array}$

\section{References}

1. Spalding, R.F.; Mathews, T.D. Stalagmites from Caves in the Bahamas: Indicators of Low Sea Level Stand. Quat. Res. 1972, 2, 470-472. [CrossRef]

2. Ginés, A.; Ginés, J. Consideraciones sobre los Mecanismos de Fosilización de la "Cova de sa Bassa Blanca" y su Paralelismo con Formaciones Marinas del Cuaternario. Bolletí de la Societat d'Història Nat. de les Balears 1974, 19, 11-28. (In Spanish)

3. Li, W.X.; Lundberg, J.; Dickin, A.P.; Ford, D.C.; Schwarcz, H.P.; McNutt, R.; Williams, D. High-Precision Mass-Spectrometric Uranium-Series Dating of Cave Deposits and Implications for Palaeoclimate Studies. Nature 1989, 339, 534-536. [CrossRef]

4. Richards, D.A.; Smart, P.L.; Lawrence Edwards, R. Maximum Sea Levels for the Last Glacial Period from U-Series Ages of Submerged Speleothems. Nature 1994, 367, 357-360. [CrossRef] 
5. Lundberg, J.; Ford, D.C. Late Pleistocene Sea Level Change in the Bahamas from Mass Spectrometric U-Series Dating of Submerged Speleothem. Quat. Sci. Rev. 1994, 13, 1-14. [CrossRef]

6. Antonioli, F.; Furlani, S.; Montagna, P.; Stocchi, P. The Use of Submerged Speleothems for Sea Level Studies in the Mediterranean Sea: A New Perspective Using Glacial Isostatic Adjustment (GIA). Geosciences 2021, 11, 77. [CrossRef]

7. Gascoyne, M.; Benjamin, G.J.; Schwarcz, H.P.; Ford, D.C. Sea-Level Lowering during the Illinoian Glaciation: Evidence from a Bahama "Blue Hole". Science 1979, 205, 806-808. [CrossRef] [PubMed]

8. Harmon, R.S.; Land, L.S.; Mitterer, R.M.; Garrett, P.; Schwarcz, H.P.; Larson, G.J. Bermuda Sea Level During the Last Interglacial. Nature 1981, 289, 481-483. [CrossRef]

9. Wainer, K.A.I.; Rowe, M.P.; Thomas, A.L.; Mason, A.J.; Williams, B.; Tamisiea, M.E.; Williams, F.H.; Düsterhus, A.; Henderson, G.M. Speleothem Evidence for MIS 5c and 5a Sea Level Above Modern Level at Bermuda. Earth Planet. Sci. Lett. 2017, 457, 325-334. [CrossRef]

10. Moseley, G.; Smart, P.L.; Richards, D.A.; Hoffmann, D.L. Speleothem Constraints on Marine Isotope Stage (MIS) 5 Relative Sea Levels, Yucatán Peninsula, Mexico. J. Quat. Sci. 2013, 28, 293-300. [CrossRef]

11. Moseley, G.E.; Richards, D.A.; Smart, P.L.; Standish, C.D.; Hoffmann, D.L.; ten Hove, H.; Vinn, O. Early-Middle Holocene Relative Sea-Level Oscillation Events Recorded in a Submerged Speleothem from the Yucatán Peninsula, Mexico. Holocene 2015, 25, 1511-1521. [CrossRef]

12. De Waele, J.; D’Angeli, I.M.; Bontognali, T.; Tuccimei, P.; Scholz, D.; Jochum, K.P.; Columbu, A.; Bernasconi, S.M.; Fornós, J.J.; Grau González, E.R.; et al. Speleothems in a North Cuban Cave Register Sea-Level Changes and Pleistocene Uplift Rates. Earth Surf. Process. Landf. 2018, 43, 2313-2326. [CrossRef]

13. Miklavič, B.; Yokoyama, Y.; Urata, K.; Miyairi, Y.; Kan, H. Holocene Relative Sea Level History from Phreatic Overgrowths on Speleothems (POS) on Minami Daito Island, Northern Philippine Sea. Quat. Int. 2018, 471, 359-368. [CrossRef]

14. Van Hengstum, P.J.; Richards, D.A.; Onac, B.P.; Dorale, J.A. Coastal Caves and Sinkholes. In Handbook of Sea-Level Research; John Wiley \& Sons, Ltd.: Chichester, UK, 2015; pp. 83-103.

15. Dumitru, O.A.; Polyak, V.J.; Asmerom, Y.; Onac, B.P. Last Interglacial (Sensu Latu, 130 To 75 Ka) Sea Level History from Cave Deposits: A Global Standardized Database. Earth Syst. Sci. Data Discuss. 2020, 2020, 1-25. [CrossRef]

16. Mylroie, J.E.; Lace, M.J.; Kambesis, P.N.; Mylroie, J.R. Karst Processes and Estuarine Coastlines. In Encyclopedia of Estuaries; Encyclopedia of Earth Sciences Series; Kennish, M.J., Ed.; Springer: Dordrecht, The Netherlands, 2016; pp. 373-380, ISBN 978-94-017-8801-4.

17. Emery, K.O.; Uchupi, E. Western North Atlantic Ocean: Topography, Rocks, Structure, Water, Life, and Sediments. Amer. Ass. Pet. Geol. 1972, 17, A532.

18. Smart, P.L.; Beddows, P.A.; Coke, J.; Doerr, S.; Smith, S.; Whitaker, F.F. Cave Development on the Caribbean Coast of the Yucatán Peninsula, Quintana Roo, Mexico. In Perspectives on Karst Geomorphology, Hydrology, and Geochemistry-A Tribute Volume to Derek, C. Ford and William B. White; Harmon, R.S., Wicks, C.M., Eds.; Geological Society of America: Boulder, CO, USA, 2006; Volume 404, ISBN 9780813724041.

19. De Waele, J.; D’Angeli, I.M.; Tisato, N.; Tuccimei, P.; Soligo, M.; Ginés, J.; Ginés, A.; Fornós, J.J.; Villa, I.M.; Grau González, E.R.; et al. Coastal Uplift Rate at Matanzas (Cuba) Inferred From MIS5e Phreatic Overgrowths on Speleothems. Terra Nov. 2017, 29, 98-105. [CrossRef]

20. Cabrera, M.; Penalver, L.L. Contribuci_On A La Estratigraf_Ia De Los Dep_Ositos Cuaternarios De Cuba. Cuatern. Geomorfol. Rev. Soc. Esp. Geomorfol. Asoc. Esp. Estud. Cuatern. 2001, 15, 37-49.

21. Hearty, P.J.; Kindler, P. The Stratigraphy and Surficial Geology of New Providence and Surrounding Islands, Bahamas. J. Coast. Res. 1997, 13, 798-812.

22. Vacher, L.; Quinn, T. Geology and Hydrogeology of Carbonate Islands; Elsevier Science: Amsterdam, The Netherlands, 1997; ISBN 9780080532479.

23. Ohde, S.; Elderfield, H. Strontium Isotope Stratigraphy of Kita-Daito-Jima Atoll, North Philippine Sea: Implications for Neogene Sea-Level Change and Tectonic History. Earth Planet. Sci. Lett. 1992, 113, 473-486. [CrossRef]

24. Tam, E.; Yokoyama, Y. A Review of MIS 5e Sea-Level Proxies around Japan. Earth Syst. Sci. Data 2021, 13, 1477-1497. [CrossRef]

25. Stocchi, P.; Antonioli, F.; Montagna, P.; Pepe, F.; Lo Presti, V.; Caruso, A.; Corradino, M.; Dardanelli, G.; Renda, P.; Frank, N.; et al. A Stalactite Record of Four Relative Sea-Level Highstands during the Middle Pleistocene Transition. Quat. Sci. Rev. 2017, 173, 92-100. [CrossRef]

26. Surić, M.; Richards, D.A.; Hoffmann, D.L.; Tibljaš, D.; Juračić, M. Sea-Level Change during MIS 5a Based on Submerged Speleothems from the Eastern Adriatic Sea (Croatia). Mar. Geol. 2009, 262, 62-67. [CrossRef]

27. Vesica, P.L.; Tuccimei, P.; Turi, B.; Fornós, J.J.; Ginés, A.; Ginés, J. Late Pleistocene Paleoclimates and Sea-Level Change in the Mediterranean as Inferred from Stable Isotope and U-Series Studies of Overgrowths on Speleothems, Mallorca, Spain. Quat. Sci. Rev. 2000, 19, 865-879. [CrossRef]

28. Tuccimei, P.; Soligo, M.; Ginés, J.; Ginés, A.; Fornós, J.; Kramers, J.; Villa, I.M. Constraining Holocene Sea Levels Using U-Th Ages of Phreatic Overgrowths on Speleothems from Coastal Caves in Mallorca (Western Mediterranean). Earth Surf. Process. Landf. 2010, 35, 782-790. [CrossRef]

29. Dorale, J.A.; Onac, B.P.; Fornós, J.J.; Ginés, J.; Ginés, A.; Tuccimei, P.; Peate, D.W. Sea-Level Highstand 81,000 Years Ago in Mallorca. Science 2010, 327, 860-863. [CrossRef] 
30. Polyak, V.J.; Onac, B.P.; Fornós, J.J.; Hay, C.; Asmerom, Y.; Dorale, J.A.; Ginés, J.; Tuccimei, P.; Ginés, A. A Highly Resolved Record of Relative Sea Level in the Western Mediterranean Sea during the Last Interglacial Period. Nat. Geosci. 2018, 11, 860-864. [CrossRef]

31. Lucia, G.; Polyak, V.J.; Ginés, J.; Fornòs, J.J.; Ginés, A.; Asmerom, Y.; Onac, B.P. Chronology of Middle Pleistocene Coastal Karst Evolution and Relative Sea-Level Changes in Mallorca. J. Coast. Res. 2020, in press. [CrossRef]

32. Alessio, M.; Allegri, L.; Antonioli, F.; Belluomini, G.; Ferranti, L.; Improta, S.; Manfra, L.; Proposito, A. Risultati Preliminari Relativi alla Datazione di Speleotemi Sommersi Nelle Fasce Costiere del Tirreno Centrale. G. Geol. 1992, 54, 165-194. (In Italian)

33. Dutton, A.; Scicchitano, G.; Monaco, C.; Desmarchelier, J.M.; Antonioli, F.; Lambeck, K.; Esat, T.M.; Fifield, L.K.; McCulloch, M.T.; Mortimer, G. Uplift Rates Defined by U-Series and 14C Ages of Serpulid-Encrusted Speleothems from Submerged Caves Near Siracusa, Sicily (Italy). Quat. Geochronol. 2009, 4, 2-10. [CrossRef]

34. Dutton, A.; Bard, E.; Antonioli, F.; Esat, T.M.; Lambeck, K.; McCulloch, M.T. Phasing and Amplitude of Sea-Level and Climate Change during the Penultimate Interglacial. Nat. Geosci. 2009, 2, 355-359. [CrossRef]

35. Surić, M.; Lončarić, R.; Lončar, N. Submerged Caves of Croatia: Distribution, Classification and Origin. Environ. Earth Sci. 2010, 61, 1473-1480. [CrossRef]

36. Furlani, S.; Antonioli, F.; Gambin, T.; Biolchi, S.; Formosa, S.; Lo Presti, V.; Mantovani, M.; Anzidei, M.; Calcagnile, L.; Quarta, G. Submerged Speleothem in Malta Indicates Tectonic Stability throughout the Holocene. Holocene 2018, 28, 1588-1597. [CrossRef]

37. Alessio, M.; Allegri, L.; Antonioli, F.; Belluomini, G.; Impronta, S.; Manfra, L.; Preite, M. La Curva di Risalita del Mare Tirreno Negli Ultimi 43 Ka Ricavata da Datazioni Su Speleotemi Sommersi E Dati Archeologici. Mem. Descr. Serv. Geol. Naz. 1994, 52, 261-276.

38. Antonioli, F.; Bard, E.; Potter, E.K.; Silenzi, S.; Improta, S. 215-ka History of Sea-Level Oscillations from Marine and Continental Layers in Argentarola Cave Speleothems (Italy). Glob. Planet. Chang. 2004, 43, 57-78. [CrossRef]

39. Furlani, S.; Pappalardo, M.; Gómez-Pujol, L.; Chelli, A. The Rock Coast of the Mediterranean and Black Seas. Geol. Soc. Mem. 2014, 40, 89-123. [CrossRef]

40. Rohling, E.J.; Abu-Zied, R.; Casford, C.S.L.; Hayes, A.; Hoogakker, B.A.A. The Mediterranean Sea: Present and Past. In Physical Geography of the Mediterranean Basin; Oxford University Press: Oxford, UK, 2009; ISBN 978-0-19-926803-0.

41. Giese, P.; Morelli, C. La Struttura Della Crosta Terrestre in Italia. Accad. Naz. Lincei 1973, 183, 317-362. (In Italian)

42. Sulli, A.; Zizzo, E.; Spatola, D.; Gasparo Morticelli, M.; Agate, M.; Lo Iacono, C.; Gargano, F.; Pepe, F.; Ciaccio, G. Growth and Geomorphic Evolution of the Ustica Volcanic Complex at the Africa-Europe Plate Margin (Tyrrhenian Sea). Geomorphology 2021, 374, 107526. [CrossRef]

43. Bousquet, J.C.; Lanzafame, G. Transition from Tyrrhenian basin extension to collisional tectonics: Evidence of N-S compression during the recent Quaternary at Ustica (southern Tyrrhenian Sea, Italy). C.R. Acad. Sc. Paris 1995, 321, 781-787.

44. Bonomo, R.; Ricci, V. Application of Unconformity-Bounded Stratigraphic (UBS) Units to the Geological Survey of the Volcanic Island Ustica (Italy). In Stratigraphy and Geology of Volcanic Areas; Groppelli, G., Viereck-Goette, L., Eds.; Geological Society of America: Boulder, CO, USA, 2010; Volume 464, pp. 51-61. ISBN 9780813724645.

45. Romano, R.; Sturiale, C. L'isola di Ustica: Studio Geo-Vulcanologico e Magmatologico. Riv. Miner. Sicil. 1971, 22, 3-61. (In Italian)

46. De Vita, S. Assetto Geologico-Strutturale ed Evoluzione Vulcanologica Dell'isola di Ustica (Stratigrafia, Tettonica e Meccanismi Eruttivi). Ph.D. Thesis, Università degli Studi di Napoli Federico II, Napoli, Italy, 1993.

47. De Vita, S.; Guzzetta, G.; Orsi, G. Deformational Features of the Ustica Volcanic Island in the Southern Tyrrhenian Sea (Italy). Terra Nov. 1995, 7, 623-629. [CrossRef]

48. Peccerillo, A. Plio-Quaternary Volcanism in Italy; Springer: Berlin/Heidelberg, Germany, 2005; ISBN 978-3-540-25885-8.

49. De Vita, S.; Laurenzi, M.A.; Orsi, G.; Voltaggio, M. Application of 40ar/39ar and 230th Dating Methods to the Chronostratigraphy of Quaternary Basaltic Volcanic Areas: The Ustica Island Case History. Quat. Int. 1998, 47-48, 117-127. [CrossRef]

50. Cinque, A.; Civetta, L.; Orsi, G.; Peccerillo, A. Geology and geochemistry of the Island of Ustica (Southern Tyrrhenian Sea). Boll. Soc. Ital. Miner. Pet. 1998, 43, 987-1002.

51. Furlani, S.; Antonioli, F.; Cavallaro, D.; Chirco, P.; Caldareri, F.; Martin, F.F.; Morticelli, M.G.; Monaco, C.; Sulli, A.; Quarta, G.; et al. Tidal Notches, Coastal Landforms and Relative Sea-Level Changes during the Late Quaternary at Ustica Island (Tyrrhenian Sea, Italy). Geomorphology 2017, 299, 94-106. [CrossRef]

52. De Vita, S.; Foresta Martin, F. The Palaeogeographic Setting and the Local Environmental Impact of the 130 Ka Falconiera Tuff-Cone Eruption (Ustica Island, Italy). Ann. Geophys. 2017, 60. [CrossRef]

53. De Vita, S.; Orsi, G. I Terrazzi Marini dell'isola di Ustica (Mar Tirreno Meridionale, Italia). Mem. Descr. Carta Geol. D'It 1994, 52, 405-406. (In Italian)

54. Incandela, A. Deformazioni Neogeniche Nelle Isole di Favignana e Levanzo (Isole Egadi). Mem. Soc. Geol. It. 1996, 51, 129-135. (In Italian)

55. Abate, B.; Incandela, A.; Renda, P. Carta Geologica delle Isole di Favignana e Levanzo; University of Palermo: Palermo, Italy, 1997.

56. Lo Presti, V.; Antonioli, F.; Palombo, M.R.; Agnesi, V.; Biolchi, S.; Calcagnile, L.; di Patti, C.; Donati, S.; Furlani, S.; Merizzi, J.; et al. Palaeogeographical Evolution of the Egadi Islands (Western Sicily, Italy). Implications for Late Pleistocene and Early Holocene Sea Crossings by Humans and Other Mammals in the Western Mediterranean. Earth. Sci. Rev. 2019, 194, 160-181. [CrossRef]

57. Hearty, P.J.; Miller, G.H.; Stearns, C.E.; Szabo, B.J. Aminostratigraphy of Quaternary Shorelines in the Mediterranean Basin. Geol. Soc. Am. Bull. 1986, 97, 850-858. [CrossRef] 
58. Antonioli, F.; Cremona, G.; Immordino, F.; Puglisi, C.; Romagnoli, C.; Silenzi, S.; Valpreda, E.; Verrubbi, V. New Data on the Holocenic Sea-Level Rise in NW Sicily (Central Mediterranean Sea). Glob. Planet. Chang. 2002, 34, 121-140. [CrossRef]

59. Antonioli, F.; Ferranti, L.; Stocchi, P.; Deiana, G.; Lo Presti, V.; Furlani, S.; Marino, C.; Orru, P.; Scicchitano, G.; Trainito, E.; et al. Morphometry and Elevation of the Last Interglacial Tidal Notches in Tectonically Stable Coasts of the Mediterranean Sea. Earth Sci. Rev. 2018, 185, 600-623.

60. Pons-Branchu, E.; Douville, E.; Roy-Barman, M.; Dumont, E.; Branchu, P.; Thil, F.; Frank, N.; Bordier, L.; Borst, W. A Geochemical Perspective on Parisian Urban History Based on U-Th Dating, Laminae Counting and Yttrium and REE Concentrations of Recent Carbonates in Underground Aqueducts. Quat. Geochronol. 2014, 24, 44-53. [CrossRef]

61. Ludwig, K.R.; Titterington, D.M. Calculation of 230Th U Isochrons, Ages, and Errors. Geochim. Cosmochim. Acta 1994, 58, 5031-5042. [CrossRef]

62. Cheng, H.; Lawrence Edwards, R.; Shen, C.C.; Polyak, V.J.; Asmerom, Y.; Woodhead, J.; Hellstrom, J.; Wang, Y.; Kong, X.; Spötl, C.; et al. Improvements in 230Th Dating, 230Th and 234U Half-Life Values, and U-Th Isotopic Measurements by Multi-Collector Inductively Coupled Plasma Mass Spectrometry. Earth Planet. Sci. Lett. 2013, 371-372, 82-91. [CrossRef]

63. Jaffey, A.H.; Flynn, K.F.; Glendenin, L.E.; Bentley, W.C.; Essling, A.M. Precision Measurement of Half-Lives and Specific Activities of U235 and U238. Phys. Rev. C 1971, 4, 1889-1906. [CrossRef]

64. Hellstrom, J. U-Th Dating of Speleothems with High Initial ${ }^{230}$ Th Using Stratigraphical Constraint. Quat. Geochronol. 2006, 1, 289-295. [CrossRef]

65. Antonioli, F.; Chemello, R.; Improta, S.; Riggio, S. Dendropoma Lower Intertidal Reef Formations and Their Palaeoclimatological Significance, NW Sicily. Mar. Geol. 1999, 161, 155-170. [CrossRef]

66. Reimer, P.J.; Austin, W.E.N.; Bard, E.; Bayliss, A.; Blackwell, P.G.; Bronk Ramsey, C.; Butzin, M.; Cheng, H.; Edwards, R.L.; Friedrich, M.; et al. The IntCal20 Northern Hemisphere Radiocarbon Age Calibration Curve (0-55 cal kBP). Radiocarbon 2020, 62, 725-757. [CrossRef]

67. Calcagnile, L.; Maruccio, L.; Scrimieri, L.; delle Side, D.; Braione, E.; D’Elia, M.; Quarta, G. Development and application of facilities at the Centre for Applied Physics, Dating and Diagnostics (CEDAD) at the University of Salento during the last 15 years. Nucl. Instrum. Methods Phys. Res. Sect. B Beam Interact. Mater. At. 2019, 456, 252-256. [CrossRef]

68. Heaton, T.J.; Köhler, P.; Butzin, M.; Bard, E.; Reimer, R.W.; Austin, W.E.N.; Bronk Ramsey, C.; Grootes, P.M.; Hughen, K.A.; Kromer, B.; et al. Marine20-The Marine Radiocarbon Age Calibration Curve (0-55,000 cal BP). Radiocarbon 2020, 62, 779-820. [CrossRef]

69. Siani, G.; Paterne, M.; Arnold, M.; Bard, E.; Métivier, B.; Tisnerat, N.; Bassinot, F. Radiocarbon Reservoir Ages in the Mediterranean Sea and Black Sea. Radiocarbon 2000, 42, 271-280. [CrossRef]

70. Farrell, W.E.; Clark, J.A. On Postglacial Sea Level. Geophys. J. R. Astron. Soc. 2007, 46, 647-667. [CrossRef]

71. Spada, G.; Stocchi, P. SELEN: A Fortran 90 Program for Solving the "Sea-Level Equation". Comput. Geosci. 2007, 33, 538-562. [CrossRef]

72. Stocchi, P.; Vacchi, M.; Lorscheid, T.; de Boer, B.; Simms, A.R.; van de Wal, R.S.W.; Vermeersen, B.L.A.; Pappalardo, M.; Rovere, A. MIS 5e Relative Sea-Level Changes in the Mediterranean Sea: Contribution of Isostatic Disequilibrium. Quat. Sci. Rev. 2018, 185, 122-134. [CrossRef]

73. Peltier, W.R. Global Glacial Isostasy and the Surface of the Ice-Age Earth: The ICE-5G (VM2) Model and GRACE. Annu. Rev. Earth Planet. Sci. 2004, 32, 111-149. [CrossRef]

74. Lisiecki, L.E.; Raymo, M.E. A Pliocene-Pleistocene Stack of 57 Globally Distributed Benthic $\Delta 180$ Records. Paleoceanography 2005, 20, 1-17. [CrossRef]

75. Argus, D.F.; Peltier, W.R.; Drummond, R.; Moore, A.W. The Antarctica Component of Postglacial Rebound Model ICE-6G_C (VM5a) Based on GPS Positioning, Exposure Age Dating of Ice Thicknesses, and Relative Sea Level Histories. Geophys. J. Int. 2014, 198, 537-563. [CrossRef]

76. De Boer, B.; Stocchi, P.; van de Wal, R.S.W. A Fully Coupled 3-D Ice-Sheet-Sea-Level Model: Algorithm and Applications. Geosci. Model. Dev. 2014, 7, 2141-2156. [CrossRef]

77. De Boer, B.; Stocchi, P.; Whitehouse, P.L.; van de Wal, R.S.W. Current State and Future Perspectives on Coupled Ice-Sheet-SeaLevel Modelling. Quat. Sci. Rev. 2017, 169, 13-28. [CrossRef]

78. Blanchon, P.; Eisenhauer, A.; Fietzke, J.; Liebetrau, V. Rapid Sea-Level Rise and Reef Back-Stepping at the Close of the Last Interglacial Highstand. Nature 2009, 458, 881-884. [CrossRef]

79. Waelbroeck, C.; Labeyrie, L.; Michel, E.; Duplessy, J.C.; McManus, J.F.; Lambeck, K.; Balbon, E.; Labracherie, M. Sea-level and Deep Water Temperature Changes Derived from Benthic Foraminifera Isotopic Records. Quat. Sci. Rev. 2002, 21, 295-305. [CrossRef]

80. Toker, E.; Sivan, D.; Stern, E.; Shirman, B.; Tsimplis, M.; Spada, G. Evidence for Centennial Scale Sea Level Variability During the Medieval Climate Optimum (Crusader Period) in Israel, Eastern Mediterranean. Earth Planet. Sci. Lett. 2012, 315-316, 51-61. [CrossRef]

81. Pagliarulo, R.; Antonioli, F.; Anzidei, M. Sea Level Changes since the Middle Ages along the Coast of the Adriatic Sea: The case of St. Nicholas Basilica, Bari, Southern Italy. Quat. Int. 2013, 288, 139-145. [CrossRef]

82. Lambeck, K.; Antonioli, F.; Anzidei, M.; Ferranti, L.; Leoni, G.; Scicchitano, G.; Silenzi, S. Sea Level Change along the Italian Coast During the Holocene and Projections for the Future. Quat. Int. 2011, 232, 250-257. [CrossRef] 
83. Antonioli, F.; Silenzi, S.; Frisia, S. Tyrrhenian Holocene Palaeoclimate Trends from Spelean Serpulids. Quat. Sci. Rev. 2001, 20, 1661-1670. [CrossRef]

84. Aucelli, P.; Cinque, A.; Mattei, G.; Pappone, G. Historical Sea Level Changes and Effects on the Coasts of Sorrento Peninsula (Gulf of Naples): New Constrains from Recent Geoarchaeological Investigations. Palaeogeogr. Palaeoclimatol. Palaeoecol. 2016, 463, 112-125. [CrossRef]

85. Gowan, E.; Rovere, A.; Ryan, D.; Richiano, S.; Montes, A.; Pappalardo, M.; Aguirre, M. Last Interglacial (MIS 5e) Sea-Level Proxies in Southeastern South America. Earth Syst. Sci. Data Discuss. 2020, 1-40. [CrossRef]

86. Bard, E.; Antonioli, F.; Silenzi, S. Sea-Level during the Penultimate Interglacial Period Based on a Submerged Stalagmite from Argentarola Cave (Italy). Earth Planet. Sci. Lett. 2002, 196, 135-146. [CrossRef]

87. Bard, E.; Hamelin, B.; Fairbanks, R.G.; Zindler, A.; Mathieu, G.; Arnold, M. U/Th and 14C Ages of Corals from Barbados and Their Use for Calibrating the 14C Time Scale beyond 9000 Years B.P. Nucl. Inst. Methods Phys. Res. B 1990, 52, 461-468. [CrossRef]

88. Blanchon, P.; Shaw, J. Reef Drowning During the Last Deglaciation: Evidence for Catastrophic Sea-Level Rise and Ice-Sheet Collapse. Geology 1995, 23, 4-8. [CrossRef] 